\title{
Combining chemo-, hormonal and targeted therapies to treat breast cancer (Review)
}

\author{
LINDA S. STEELMAN ${ }^{1}$, PATRICK M. NAVOLANIC ${ }^{1}$, RICHARD A. FRANKLIN ${ }^{1}$, ANTONIO BONATI ${ }^{2}$, \\ MASSIMO LIBRA $^{3}$, FRANCA STIVALA ${ }^{3}$, ALBERTO M. MARTELLI ${ }^{4,5}$ and JAMES A. McCUBREY ${ }^{1}$ \\ ${ }^{1}$ Department of Microbiology and Immunology, Brody School of Medicine at East Carolina University, Greenville, \\ NC 27858, USA; ${ }^{2}$ Department of Clinical Sciences, University of Parma, Unit of Hematology and Bone-Marrow \\ Transplantation, University Hospital of Parma, Parma; ${ }^{3}$ Department of Biomedical Sciences, University of Catania, \\ Catania; ${ }^{4}$ Department of Human Anatomical Sciences, University of Bologna; ${ }^{5}$ IGM-CNR, c/o IOR, Bologna, Italy
}

Received December 17, 2007; Accepted January 22, 2008

\begin{abstract}
Breast cancer ranks as the second most common cause of cancer death among women in the United States. Anticancer agents are an important component of breast cancer therapy. Drugs frequently used to treat breast cancer include methotrexate, 5-fluorouracil (5-FU), cyclophosphamide, anthracyclines, taxanes, trastuzumab, tamoxifen and aromatase inhibitors. These agents inhibit breast cancer progression by a variety of different mechanisms. Mutations may occur in cancer cells, which result in the elevated expression or constitutive activation of various growth factor receptors. The Raf/ MEK/ERK and PI3K/Akt pathways are often activated by mutations in these growth factor receptors. These pathways are regulated by upstream Ras, which is mutated in $20-30 \%$ of human cancers. Downstream B-Raf and PI3K are also activated by mutation. Many of the events elicited by the Raf/MEK/ERK and PI3K/Akt pathways have direct effects on survival and the proliferative pathways. Aberrant regulation of the Raf/MEK/ ERK and PI3K/Akt pathways can contribute to uncontrolled cell growth and lead to malignant transformation. Effective targeting of these pathways may result in the suppression of cell growth and the death of malignant cells. This review focuses on the targeting of the Raf/MEK/ERK and PI3K/Akt pathways with small molecule inhibitors, as well as on the effects of conventional chemo- and hormonal therapies in the treatment of breast cancer.
\end{abstract}

\section{Contents}

1. Introduction

2. Methotrexate and 5-fluorouracil

Correspondence to: Dr Linda S. Steelman, Department of Microbiology and Immunology, Brody School of Medicine at East Carolina University, Greenville, NC 27858, USA

E-mail: steelmanl@ecu.edu

Key words: conventional therapy, targeted therapy, signal transduction inhibitors, breast cancer
3. Cyclophosphamide

4. Anthracyclines

5. Taxanes

6. Trastuzumab

7. Tamoxifen

8. Aromatase inhibitors

9. Overview of the Ras/Raf/MEK/ERK pathway

10. Effects of the Raf/MEK/ERK pathway on the regulation of apoptosis

11. Roles of the Ras/Raf/MEK/ERK pathway in neoplasia

12. Overview of the PI3K/Akt pathway

13. Interactions between the PI3K/Akt and Raf/MEK/ERK pathways which regulate apoptosis

14. Role of the PI3K/Akt pathway in neoplasia

15. Signaling pathways and breast cancer

16. Aberrant regulation of apoptosis may contribute to breast cancer and subsequent drug resistance

17. Therapeutic targeting of the Raf/MEK/ERK pathway

18. Combination therapies to enhance toxicity

19. Combining signal transduction inhibitors with antibody, hormonal and chemotherapeutic-based therapies

20. Enhancing the effects of Ras/Raf/MEK/ERK pathway inhibitors by combination therapy

21. Role of the Raf/MEK/ERK pathway in drug resistance to reactive oxygen intermediate-inducing cancer treatments

22. Conclusions

\section{Introduction}

Over 210,000 new cases of breast cancer are diagnosed in the United States each year (1). Accordingly, approximately 1 in 7 women in the United States will be diagnosed with breast cancer during their lifetime (2). It is the cause of death of over 40,000 women in the United States each year, ranking it as the second most common cause of cancer death among women, and is a leading cause of cancer death in developed countries worldwide. There is consequently an urgent need to improve breast cancer therapy. Many drugs have been demonstrated to extend survival in breast cancer patients. The anticancer agents commonly used to treat the disease include methotrexate, 5-fluorouracil (5-FU), cyclophosphamide, anthracyclines, 
taxanes, trastuzumab, tamoxifen and aromatase inhibitors. The mechanisms by which these agents inhibit breast cancer progression vary from drug to drug.

\section{Methotrexate and 5-fluorouracil}

DNA synthesis requires thymidine 5'-triphosphate (TTP), which is synthesized from thymidine 5'-monophosphate (TMP). Thymidylate synthetase generates TMP by catalyzing the transfer of a methyl group from $N^{5}, N^{10}$-methylenetetrahydrofolate to 2'-deoxyuridine 5'-monophosphate (dUMP). Methotrexate and 5-FU treatment each prevent TMP synthesis. Thymidylate synthetase is irreversibly inhibited by 5-fluoro-2'deoxyuridine 5'-monophosphate (FdUMP), which is produced by 5 -FU. In contrast, methotrexate treatment blocks TMP synthesis by preventing the synthesis of $N^{5}, N^{10}$-methylenetetrahydrofolate.

Methotrexate contains a single glutamic acid residue. Folylpoly- $\gamma$-glutamate synthetase (FPGS) catalyzes the addition of one or more glutamic acid moieties to methotrexate. Methotrexate and its polyglutamylated derivatives inhibit dihydrofolate (DHF) reductase (DHFR). DHFR reduces folate to DHF and DHF to tetrahydrofolate (THF). Serine hydroxy-methyltransferase converts THF to $N^{5}, N^{10}$ methylenetetrahydrofolate. Methotrexate treatment reduces TMP production by eliminating a source of $N^{5}, N^{10}$-methylenetetrahydrofolate synthesis. Reduction of TMP levels by treatment with methotrexate or 5-FU inhibits TTP production. This blocks cell proliferation by preventing DNA synthesis.

\section{Cyclophosphamide}

The hepatic metabolism converts cyclophosphamide to 4-hydroxycyclophosphamide, the tautomerization of which yields aldophosphamide. Acrolein and $N, N$-bis-2-(2-chloroethyl) phosphorodiamidate are produced by the spontaneous cleavage of aldophosphamide. DNA is alkylated by $N, N$-bis-2(2-chloroethyl) phosphorodiamidate at multiple sites. The $N^{7}$ position of guanine is a site that is particularly susceptible to alkylation by $N, N$-bis-2-(2-chloroethyl) phosphorodiamidate. Alkylation of the $N^{7}$ position of guanine caused by cyclophosphamide treatment stabilizes the enol tautomer of guanine, which causes guanine to pair with thymine instead of cytosine. DNA damage caused by cyclophosphamide treatment induces apoptotic cell death $(3,4)$.

\section{Anthracyclines}

Anthracyclines frequently used to treat breast cancer include doxorubicin (Adriamycin) and epirubicin. Anthracyclines disrupt DNA structure by intercalating between adjacent DNA base pairs. Disruption of the DNA structure by anthracyclines inhibits the synthesis of both DNA and RNA $(5,6)$. The intercalation of anthracyclines within DNA also induces DNA cleavage mediated by topoisomerase II isoforms $(7,8)$, including topoisomerase II $\alpha$, topoisomerase II $\alpha-1$ and topoisomerase IIß-2 (9-12). This DNA cleavage likely makes an important contribution to the cytotoxicity of anthracyclines, because less expression of topoisomerase II $\alpha$ is correlated with decreased anthracycline sensitivity (13). These anthracyclines induce apoptotic cell death.

\section{Taxanes}

The mitotic spindle of a dividing cell functions to distribute chromatids to each daughter cell. Mitotic spindles are composed of microtubules. Cellular control of microtuble polymerization and depolymerization is essential for proper spindle function. Taxanes disrupt mitotic spindle function by stabilizing the microtubules (14-16), which are assembled from tubulin heterodimers. Tubulin heterodimers are composed of $\alpha$-tubulin and $\beta$-tubulin. Taxanes stabilize microtubules by binding to $\beta$-tubulin. Disruption of mitotic spindle function by taxanes prevents cell division. Taxanes frequently used to treat breast cancer include paclitaxel and docetaxel.

\section{Trastuzumab}

Trastuzumab (Herceptin) is a humanized mouse monoclonal immunoglobulin $\mathrm{G}_{1}\left(\operatorname{IgG}_{1}\right) \kappa$ antibody that binds to the extracellular domain of HER2 $(17,18)$. HER2 is amplified and overexpressed in 20-30\% of breast cancers and is associated with a poor prognosis. Endocytic degradation of HER2 is accelerated by binding to trastuzumab. The induction of HER 2 degradation by trastuzumab decreases the activity of the signal transduction cascades downstream of HER2 that promote cell cycle progression and inhibit apoptosis. These signal transduction cascades include the Raf/MEK/ERK and PI3K/PDK/Akt pathways. Their deactivation by trastuzumab treatment, which is most effective for breast cancers with either high HER2 protein levels or amplification of the gene encoding HER2 (19), prevents cell proliferation.

\section{Tamoxifen}

Tamoxifen and its metabolites inhibit the proliferation of breast cancer cells by binding to estrogen receptors (ERs) (20). ER isoforms include ER $\alpha$ and ERß (21-27), which bind together in both homodimeric and heterodimeric combinations (28-31). ERs are transcription factors that induce the expression of the proteins that promote cell cycle progression and inhibit apoptosis. These proteins include cyclin D1, which promotes cell cycle progression, and $\mathrm{Bcl}-2$, which prevents apoptosis $(32,33)$. The binding of ERs to estrogens stimulates the transcription of these genes. Tamoxifen and its metabolites compete with estrogens for the same ER $\alpha$ and ERß ligand binding sites and, upon binding, prevent the estrogens from promoting cell proliferation. This is because the transactivation potential of ERs bound to tamoxifen is less than that of ERs bound to estrogens. The treatment of MCF-7 cells with tamoxifen decreased the levels of Bcl-2 mRNA, as well as of Bcl-2 protein (34).

The transactivation potential of ERs bound to tamoxifen or its metabolites is dependent on whether $\mathrm{ER} \alpha$ or $\mathrm{ER} \beta$ isoforms are present. Tamoxifen is a partial agonist for ER $\alpha$ homodimers, but is a pure antagonist for ERß homodimers (35). The hepatic metabolism converts tamoxifen to 4-hydroxytamoxifen (4-HT), similar to tamoxifen in that it is a partial agonist for ER $\alpha$ homodimers yet a pure antagonist for ERß homodimers. The estrogenic effects of tamoxifen treatment are likely responsible for its stabilization of bone mineral density (BMD), as well as its association with increased frequencies of endometrial cancer and thromboembolic disease (36-38). 


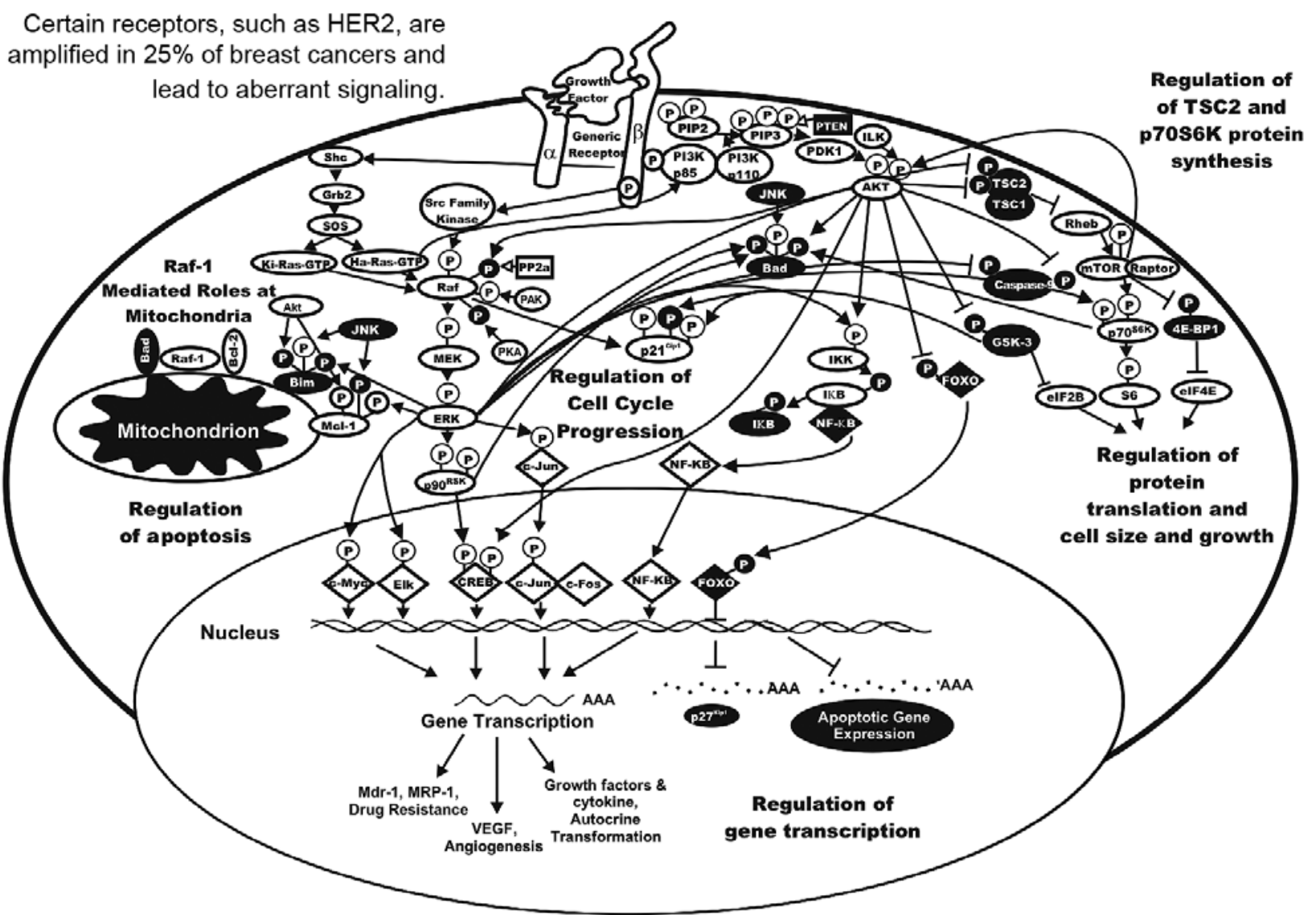

Figure 1. Overview of the Raf/MEK/ERK and PI3K/Akt pathways. The Raf/MEK/ERK and PI3K/Akt pathways are regulated by Ras as well as by various kinases. Many kinases serve to phosphorylate S/T and Y residues on Raf. Some of these phosphorylation events serve to enhance Raf activity (indicated by a black P in a white circle) whereas others serve to inhibit Raf activity (indicated by a white P in a black circle). Moreover, there are phosphatases, such as PP2A, that remove phosphates on certain regulatory residues. The PI3K/Akt pathway is also activated after receptor ligation. Akt has many downstream targets which serve to regulate cell growth and apoptosis. The downstream transcription factors regulated by these pathways are indicated in diamond-shaped outlines.

Tumor biopsy specimens from breast cancer patients are analyzed for ER $\alpha$ expression by immunohistochemisty to determine whether tamoxifen treatment is appropriate (39). Tamoxifen is only administered to breast cancer patients with $\mathrm{ER} \alpha$ positive $\left(\mathrm{ER}^{+}\right)$tumors, as its therapeutic benefit is substantially higher in breast cancer patients with $\mathrm{ER}^{+}$tumors than in those with ER negative (ER') tumors $(40,41)$. Coadministration of tamoxifen together with chemotherapeutic drugs is more effective than the administration of the same chemotherapeutic drugs without tamoxifen for the treatment of breast cancer patients with $\mathrm{ER}^{+}$tumors, but not for those with ER- tumors (42).

\section{Aromatase inhibitors}

Estrogen biosynthesis is dependent on aromatase. Aromatase inhibitors prevent the proliferation of breast cancer cells by blocking estrogen production. There are two classes of aromatase inhibitors, which differ in chemical structure and mechanism of action. Non-steroidal aromatase inhibitors, such as anastrozole and letrozole, bind reversibly to aromatase. In contrast, steroidal aromatase inhibitors, such as exemestane, bind irreversibly to aromatase. Anastrozole and letrozole have each been reported to be superior to tamoxifen in first-line therapy for post-menopausal patients with hormone receptorpositive advanced breast cancer (43-46).

\section{Overview of the Ras/Raf/MEK/ERK pathway}

The Ras/Raf/MEK/ERK pathway is activated by many growth factors and cytokines important in driving proliferation and preventing the apoptosis of breast cells (47-51). An overview of the effects of the Ras/Raf/MEK/ERK pathway on the downstream signaling pathways leading to the growth and prevention of apoptosis is presented in Fig. 1. After receptor ligation, Shc, an Src homology (SH)-2 (SH2)-domain containing protein, becomes associated with the c-terminus of the growth factor receptor (52-54) and recruits the GTP-exchange complex Grb2/Sos, resulting in the loading of membrane-bound Ras with GTP $(55,56)$. Ras:GTP then recruits Raf to the membrane and is activated, likely by an Src-family tyrosine (Y) kinase (57-59). Raf is responsible for the phosphorylation of mitogen associated/extracellular regulated kinase-1 (MEK1) (60-62). MEK1 phosphorylates extracellular regulated kinases 1 and 2 (ERKs 1 and 2) on specific threonine (T) and $\mathrm{Y}$ residues (60-62). Activated ERK1 and ERK2 serine (S)/T kinases phosphorylate and activate a variety of substrates including p90 Rsk1 (63-70), which can activate the cyclic-AMP response element binding protein (CREB) transcription factor (65). Moreover, ERK can translocate to the nucleus and phosphorylate additional transcription factors, such as Elk1, CREB and Fos, which bind the promoters of many genes, including the growth factor and cytokine genes important in stimulating the 
Raf-1 can interact with many apoptotic regulatory molecules at the mitochondrion.

ERK and Akt can phosphorylate Bim and Bad, which affects their subcellular localization and leads to their being ubiquitionated and targeted to the protesome for degradation.

The phosphorylation status of Bim and Bad influences their ability to dimerize with $\mathrm{Bcl}-2$. $\mathrm{Bcl}-\mathrm{XI}$ and $\mathrm{Mcl}-1$, which in turn alters their interactions with Bax and Bak.

p90Rsk, which is regulated by both pathways, phosphorylates CREB and stimulates Mcl-1 transcription. ERK and Akt phosphorylation of $\mathrm{Mcl}-1$ results in Mcl-1 stabilization.

ERK can phosphorylate Bcl-2, which enhances its anti-apoptotic effects.

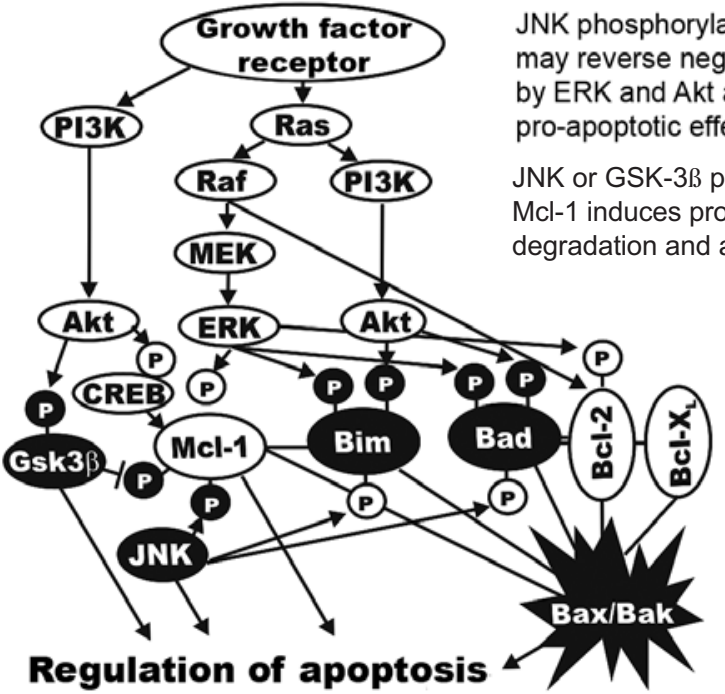
by ERK and Akt and promote the effects of Bim and Bad.

sphorylation of Mcl-1 induces proteosomal

Figure 2. Effects of the Raf/MEK/ERK and PI3K/Akt pathways on apoptotic circuity. Growth factors can induce multiple signal transduction pathways, which can affect the expression of apoptotic molecules by transcriptional and post-transcriptional mechanisms. The effects of the Raf/MEK/ERK and PI3K/Akt pathways are often counterbalanced by JNK and GSK-3ß, which can serve to promote apoptosis.

growth and survival of multiple cell types, including breast cells (63,71-81). The Raf/MEK/ERK pathway can also modulate the activity of many proteins involved in apoptosis, including Bcl-2, Bad, Bim, Mcl-1, caspase 9 and survivin (82-91). Raf-1 has many roles, independent of MEK and ERK, that are involved in the prevention of apoptosis (51). These non-MEK/ERK effects are not be sensitive to inhibition by MEK inhibitors, but may be sensitive to Raf inhibitors if they are dependent on Raf kinase activity.

Recently, Raf-1 was shown to interact with mammalian sterile 20-like kinase (MST-2) and prevent its dimerization and activation (92). MST-2 is activated by pro-apoptotic agents, such as staurosporine and Fas ligand. Raf-1, but not B-Raf, binds MST-2. Depletion of MST-2 from Raf-1 $1^{-/}$cells abrogated sensitivity to apoptosis, while overexpression of MST-2 increased sensitivity to apoptosis. It was proposed that Raf-1 might control MST-2 by sequestering it into an inactive complex. This complex of Raf-1:MST-2 is independent of MEK and downstream ERK. Raf-1 can also interact with the apoptotic signal kinase (ASK1) to inhibit apoptosis $(51,93)$. ASK1 is a general mediator of apoptosis and is induced in response to a variety of cytotoxic stresses, including tumor necrosis factor (TNF), Fas and reactive oxygen species (ROS). ASK1 appears to be involved in the activation of the Jun N-terminal kinase (JNK) and p38 MAP kinases.

\section{Effects of the Raf/MEK/ERK pathway on the regulation of apoptosis}

The Raf/MEK/ERK pathway contributes to the transcriptional regulation of $\mathrm{Bcl}-2$ family members as it can regulate $\mathrm{CREB}$ phosphorylation. CREB binds the Mcl-1 and Bcl-2 promoter regions (94-98). Moreover, the Raf/MEK/ERK pathway phosphorylates pro-apoptotic $\mathrm{Bcl} 2$ homology-3 (BH3)-only domain protein Bad, which prevents its apoptotic effects and leads it to become cytoplasmically localized $(97,99,100)$. Another MAP kinase, JNK, phosphorylates 14-3-3 proteins and results in their disassociation from cytoplasmicallylocalized $\mathrm{Bad}$, which then translocates to the mitochondrion (101). When Bad associates with Bcl-2 or Bcl- $\mathrm{X}_{\mathrm{L}}$, it promotes apoptosis by preventing them from interacting with Bax (102-108). In contrast, the anti-apoptotic Mcl-1 protein is not reported to interact with Bad (107). An overview of the effects of the Raf/MEK/ERK pathway on the prevention of apoptosis is presented in Fig. 2.

The Raf/MEK/ERK pathway can phosphorylate the BH3-only domain protein $\operatorname{Bim}(89,109)$. When Bim is phosphorylated by ERK, it is targeted for ubiquitination and degradation in the proteosome (91). Mcl-1 can bind Bim, which prevents the activation and mitochondrial translocation of Bax $(88,91)$. In contrast, JNK can phosphorylate Bim at S65, which enhances its ability to induce Bax activation and stimulates apoptosis (104). Mcl-1 can also bind pro-apoptotic Bak (107). This Mcl-1:Bak interaction can be disrupted by the binding of the BH3-only domain Noxa protein, which results in Mcl-1 being ubiquitinated and degraded in the proteosome (103). Bak can then form active dimers and induce apoptosis. Unlike Bcl-2 and $\mathrm{Bcl}-\mathrm{X}_{\mathrm{L}}$, the half-life of the Mcl-1 protein is short due to the amino terminal PEST sequence, and its expression is regulated by both transcriptional and post-translational mechanisms (110). Certain chemotherapeutic drugs, such as taxol, will induce Mcl-1 phosphorylation at sites other than those phosphorylated by ERK (T163) (88). Oxidative stress can activate JNK, which induces the phosphorylation of Mcl-1 on S121 and T163 (111). Cytokine deprivation of certain cells induces GSK-3ß, which in turn induces the phosphorylation of Mcl-1 at S159, resulting in its ubiquitination and degradation (112).

The expression of the BH3-only domain Puma and Noxa proteins is under the control of the p53 and PI3K/Akt pathways (113). Noxa interacts specifically with Mcl-1, but not with Bcl-2 or Bcl- $\mathrm{X}_{\mathrm{L}}$ (107). Bak associates with Mcl-1 and Bcl- $\mathrm{X}_{\mathrm{L}}$, but not Bcl-2. Upon the induction of Puma and Noxa by $\mathrm{p} 53$, Puma and Noxa displace Mcl-1 from Bak, which is then able to oligomerize and induce apoptosis. This may lead to Mcl-1 
degradation and apoptosis. The Raf/MEK/ERK pathway increases Mcl-1 protein levels and stability, which may lead to an increase in Mcl-1 associated with Noxa and Puma, and a decrease in free Bak levels and less apoptosis. Targeting Raf/ MEK/ERK could stimulate apoptosis by decreasing Mcl-1 levels and altering its phosphorylation state.

Human caspase 9 was originally thought to be phosphorylated by Akt, but the murine caspase 9 lacks the Akt consensus phosphorylation site (66). Caspase 9 is phosphorylated by the Raf/MEK/ERK pathway at T125, which inhibits the activation of the caspase cascade (69). Mcl-1 is a substrate for activated caspase 3, thus decreased caspase 9 activation by ERK phosphorylation will reduce caspase 3 activation and Mcl-1 cleavage, and apoptosis will be suppressed. Targeting Raf/MEK/ERK could increase caspase 9 activation and increase the apoptosis of breast cancer cells.

\section{Role of the Ras/Raf/MEK/ERK pathway in neoplasia}

Effective targeting of signal transduction pathways activated by mutations and gene amplification may be an effective means of limiting cancer growth and metastasis. The Raf/MEK/ ERK pathway can be activated by mutations/amplifications of upstream growth factor receptors. An illustration of some of the receptors, kinases and phosphatases mutated/amplified in human cancer, and how they may impact the Raf/MEK/ ERK cascade, is presented in Fig. 3.

Mutations that lead to the expression of constitutivelyactive Ras proteins have been observed in $20-30 \%$ of human cancers $(114,115)$. These are often point mutations which alter key residues affecting Ras activity, although amplification of Ras is also detected in some tumors. Mutations that result in increased Ras activity also perturb the Raf/MEK/ERK kinase cascade.

$B$-Raf has been reported to be mutated in $\sim 7 \%$ of all cancers (116). However, this frequency may change as increasing numbers of diverse tumors are examined for B-Raf mutation. Recent studies have indicated the presence of mutated alleles of Raf-1 in therapy-induced acute myelogenous leukemia (t-AML) (117), arising after the chemotherapeutic treatment of breast cancer patients. The mutated Raf- 1 genes detected were transmitted in the germ line, and were thus not a spontaneous mutation in the leukemia, but rather may have been associated with the susceptibility to induction of t-AML in the Austrian breast cancer patients.

For many years, the Raf oncogenes were not thought to be frequently mutated in human cancer; more attention to the abnormal activation of this pathway was dedicated to Ras mutations, which can regulate both the Raf/MEK/ERK and PI3K/Akt pathways. However, it was recently shown that $B$-Raf is frequently mutated in melanoma $(27-70 \%)$, papillary thyroid cancer (36-53\%), colorectal cancer (5-22\%) and ovarian cancer $(30 \%)(116,118-120)$. The reasons for mutation at $B-R a f$ and not $R a f-1$ or $A-R a f$ in melanoma patients are not entirely clear. Based on the mechanism of activation of $B$-Raf, it may be easier to select for $B-R a f$ than for either $R a f-1$ or $A$-Raf mutations. Due to the amino acids present at two key regulatory sites in the different $R a f$ isoforms, activation of $B$-Raf would require one genetic mutation, whereas activation of either Raf-1 or $A$-Raf would require two. It was recently proposed that the structure of B-Raf, Raf-1 and A-Raf may

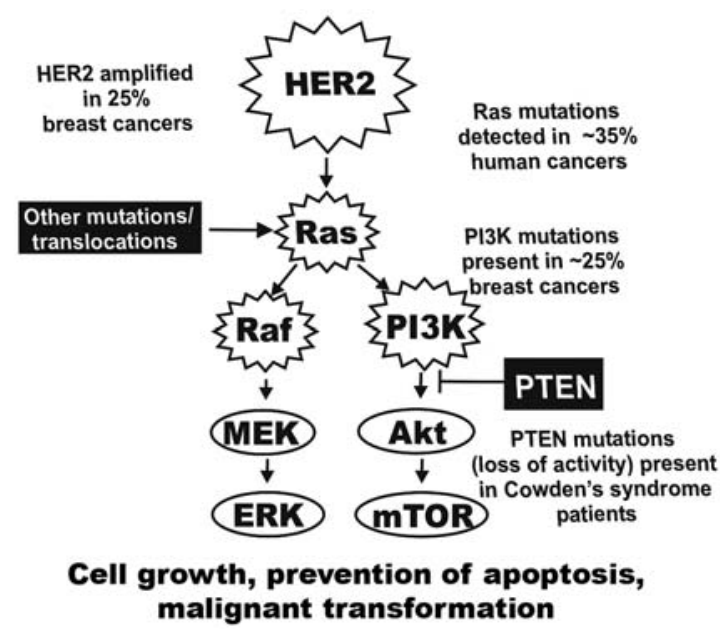

Figure 3. Sites of mutation which can result in the activation of the Raf/MEK/ ERK and PI3K/Akt cascades. Amplification of HER2 is observed in breast cancer, which can result in the activation of both the Raf/MEK/ERK and PI3K/ Akt cascades. Ras is mutated in $\sim 35 \%$ of human cancer, although not usually in breast cancer. The PI3K/PTEN/Akt pathway is also activated in breast cancer due to mutations at PI3K and PTEN. Mutations at either gene can result in Akt activation, which is associated with a poorer prognosis in breast cancer.

dictate the ability of activating mutations to occur at these molecules, which can permit the selection of oncogenic forms $(116,119,121)$. These predictions have arisen from the determination of the crystal structure of B-Raf (121) which, like many enzymes, is proposed to have small and large lobes separated by a catalytic cleft. The structural and catalytic domains of B-Raf, and the importance of the size and positioning of the small lobe, may be critical to its ability to be stabilized by certain activating mutations. In contrast, the precise substitutions in A-Raf and Raf-1 are not predicted to result in small lobe stabilization, thus preventing the selection of mutations at A-Raf and Raf-1, which would result in activated oncogenes (121). Raf-1 has been known for years to interact with heat shock protein 90 (Hsp90), which may stabilize activated Raf-1, B-Raf and A-Raf. The role played by Hsp90 in the selection of activated Raf mutations is highly speculative, yet very intriguing, and the effects of drugs which target Hsp90 will be discussed later.

The most common $B$-Raf mutation is a change at nucleotide 600 that converts a valine to a glutamic acid (V600E) (116). This B-Raf mutation accounts for over $90 \%$ of the $B$-Raf mutations found in melanoma and thyroid cancer. It has been proposed that $B$-Raf mutations may occur in certain cells that express high levels of B-Raf due to hormonal stimulation. Certain hormonal signaling events will elevate intracellular cAMP levels and result in B-Raf activation, leading to proliferation. Melanocytes and thyrocytes are two such cell types, which have elevated B-Raf expression as they are often stimulated by the appropriate hormones (122). Moreover, it is now thought that B-Raf is the most important kinase in the Raf/MEK/ERK cascade (116), with mutation at $B$-Raf activating downstream MEK and ERK. In some models, wildtype and mutant B-Raf activate Raf-1, which in turn activates MEK and ERK $(116,123,124)$. Multiple pharmaceutical/biotechnological companies are attempting to develop inhibitors which specifically target mutant B-Raf alleles, but do not inhibit WT B-Raf. 
In some cells, $B$-Raf mutations are believed to be initiating events, though not sufficient for full-blown neoplastic transformation $(125,126)$. Moreover, there appear to be cases in which certain B-Raf (V600E) and Ras mutations are not permitted in the transformation process, as they might result in the hyperactivation of Raf/MEK/ERK signaling and expression and lead to cell cycle arrest (118). In contrast, there are other situations that depend on the particular B-Raf mutation and require both B-Raf and Ras mutations for transformation. The $B$-Raf mutations in these cases result in weaker levels of B-Raf activity $(118,126)$.

Different $B$-Raf mutations have been mapped to various regions of the B-Raf protein. Some of the other B-Raf mutations are believed to result in B-Raf molecules with impaired B-Raf activity, which must signal through Raf-1 $(116,123)$. Heterodimerization between B-Raf and Raf-1 may allow the impaired B-Raf to activate Raf-1. Other mutations, such as D593V, may activate alternative signal transduction pathways (116).

\section{Overview of the PI3K/Akt pathway}

Growth factor/cytokine receptor ligation also leads to rapid activation of phosphatidylinositol 3-kinase (PI3K) (127). PI3K consists of an 85-kDa regulatory subunit, containing $\mathrm{SH} 2$ and SH3 domains, and a 110-kDa catalytic subunit $(127,128,130)$. Cytokine stimulation often creates a PI3K binding site on the cytokine receptor, which the p85 subunit $\mathrm{SH} 2$ domain associates with (127-129). The p85 subunit is then phosphorylated, leading to the activation of the p1 10 catalytic subunit. Activated PI3K phosphorylates the membrane lipid phosphatidylinositol (4,5)-bisphosphate [PtdIns $(4,5) \mathrm{P}_{2}$ ] to phosphatidylinositol $(3,4,5)$-tris-phosphate $\left[\operatorname{PtdIns}(3,4,5) \mathrm{P}_{3}\right]$, which activates PI3Kdependent kinase (PDK1). PDK1 then phosphorylates Akt at threonine 308 (T308), and a second kinase phosphorylates Akt on serine 473 (S473) (131-135).

Akt can transduce an anti-apoptotic signal by phosphorylating the downstream target proteins involved in the regulation of cell growth [e.g., glycogen synthase kinase-3ß (GSK-3ß), ASK1, Bim, Bad, MDM-2, p21 Cip1, X-linked inhibitor of apoptosis (XIAP) and the Foxo3 $\alpha$ transcription factor] $(108,131,136-145)$. Phosphorylated Foxo3 $\alpha$ loses its ability to induce Fas, p27 Kip1, Bim, Noxa and Puma gene transcription $(146,147)$. Akt also phosphorylates I-кK, which subsequently phosphorylates I- $\kappa \mathrm{B}$, resulting in its ubiquitination and subsequent degradation in proteosomes (148-160).

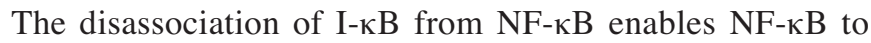
translocate into the nucleus to promote gene expression. The PI3K/Akt pathway can also phosphorylate and activate CREB, which regulates the transcription of anti-apoptotic genes, including Mcl-1 and Bcl-2 $(96,161,162)$. The PI3K pathway also results in the activation of the mammalian target of rapamycin (mTOR) and ribosomal protein kinases such as p70S6K (163-170). It is worth noting that Akt can cause the activation of specific substrates (e.g., IкK $\alpha$ and CREB) or may mediate the inactivation of other proteins [e.g., Raf-1, B-Raf (by the Akt related kinase SGK), p21 ${ }^{\text {Cip-1 }}$, Bim, Bad, procaspase 9, Foxo3 $\alpha$ and GSK-3ß].

The PI3K pathway is negatively regulated by phosphatases. PTEN (phosphatase and tensin homologue deleted on chromosome 10) is primarily a lipid phosphatase that removes the 3-phosphate from the PI3K lipid product PtdIns $(3,4,5) \mathrm{P}_{3}$ to produce PtdIns $(4,5) \mathrm{P}_{2}$, which prevents Akt activation $(129,171-175)$. PTEN is also a protein phosphatase $(174,176,177)$. Two other phosphatases, SHIP-1 and SHIP-2, remove the 5-phosphate from $\operatorname{PtdIns}(3,4,5) \mathrm{P}_{3}$ to produce PtdIns $(3,4) \mathrm{P}_{2}$ (178-182). Mutations in these phosphatases, which eliminate their activity, can lead to tumor progression. Consequently, the genes encoding these phosphatases are referred to as anti-oncogenes or tumor suppressor genes.

\section{Interactions between the PI3K/Akt and Raf/MEK/ERK pathways which regulate apoptosis}

Akt can phosphorylate Raf-1 and B-Raf and lead to their inactivation (183-186). Akt can also activate Raf-1 through a Ras-independent, but protein kinase C (PKC)-dependent, mechanism, which results in the suppression of apoptosis (187). The suppression of apoptosis in some cells by Raf and MEK requires PI3K-dependent signals (188-192).

Both the PI3K/Akt and Raf/MEK/ERK pathways contribute to the transcriptional regulation of Bcl-2 family members, as they can regulate CREB phosphorylation. CREB binds the Mcl-1 and Bcl-2 promoter regions $(94,96,98)$. Moreover, both pathways phosphorylate pro-apoptotic $\mathrm{BH} 3$-only domain protein Bad, which prevents its apoptotic effects and leads it to become cytoplasmically localized $(95,97,99,100)$. Another MAP kinase, JNK, phosphorylates 14-3-3 proteins and results in their disassociation from cytoplasmically-localized Bad, which then translocates to the mitochondrion (101). When Bad associates with $\mathrm{Bcl}-2$ or $\mathrm{Bcl}-\mathrm{X}_{\mathrm{L}}$, it promotes apoptosis by preventing $\mathrm{Bcl}-2$ or $\mathrm{Bcl}-\mathrm{X}_{\mathrm{L}}$ from interacting with $\mathrm{Bax}$ (102-108). Bad is phosphorylated in most AML specimens, suggesting that the inhibition of Bad phosphorylation may be therapeutically important in AML (193). In contrast, the antiapoptotic Mcl-1 protein is not reported to interact with Bad (107).

Both the Raf/MEK/ERK and PI3K/Akt pathways can phosphorylate the $\mathrm{BH} 3$-only domain protein $\operatorname{Bim}(89,108)$. When Bim is phosphorylated by ERK and Akt, it is targeted for ubiquitination and degradation in the proteosome (91). Mcl-1 can bind Bim, which prevents the activation and mitochondrial translocation of Bax $(88,91)$. In contrast, JNK can phosphorylate Bim at S65, which enhances its ability to induce Bax activation and hence stimulates apoptosis (104). Mcl-1 can also bind pro-apoptotic Bak (107). The Mcl-1:Bak interaction can be disrupted by the binding of the BH3-only domain Noxa protein, resulting in Mcl-1 being ubiquitinated and degraded in the proteosome (108). Bak can then form active dimers and induce apoptosis. Unlike Bcl-2 and Bcl- $\mathrm{X}_{\mathrm{L}}$, the half-life of the Mcl-1 protein is short due to the amino terminal PEST sequence, and its expression is regulated by both transcriptional and post-translational mechanisms (110).

\section{Roles of the PI3K/Akt pathway in neoplasia}

Some Ras mutations can result in PI3K/Akt activation (194-200). Mutations at the p85 subunit of PI3K have been detected in Hodgkin's lymphoma cells (201), and the p110 subunit of PI3K is frequently mutated $(\sim 25 \%)$ in breast and 
some other cancers, but not in leukemia (202-206). Mutations and hemizygous deletions of PTEN have been detected in AML and NHL (207-213). Increased Akt expression is linked to tumor progression and drug/hormonal resistance (214-217). SHIP mutations have been detected in AML $(218,219)$. Thus, many possible mechanisms could lead to elevated Akt levels.

The relationship between dysregulated PI3K activity and the onset of cancer is well documented. PI3K is the predominant growth factor-activated pathway in LNCaP human prostate carcinoma cells $(220,221)$. Other reports directly implicate PI3K activity in a variety of human tumors, including breast cancer (222), lung cancer (223), melanomas (224) and leukemia (225), among others. Activated Akt can affect the expression and regulation of the responses of hormone receptors, and can lead to the ineffectiveness of hormone ablation therapies (226-228).

Activated Akt has been reported to be detected in over $50 \%$ of primary AML samples, and is associated with a poor prognosis (229). Furthermore, the Akt pathway has been shown to be involved in the regulation of multidrug resistance protein-1 (MRP-1) and drug resistance in AML (230-233). Taken together, these data endorse the substantial role that PI3K signaling plays in oncogenesis and drug resistance. Moreover, targeted inhibition of the central components of this pathway appears to be an excellent choice for future therapeutic approaches. It has been observed that overexpression of both the Raf/MEK/ERK and PI3K/Akt pathways in AML is associated with a worse prognosis than the overexpression of a single pathway (229). Thus, the development of inhibitors which target both pathways, or the formulation of combinations of inhibitors, may prove effective in the treatment of certain cancers.

\section{Signaling pathways and breast cancer}

Breast cancer is among the most common form of cancer. Over 210,000 new cases are diagnosed in the USA each year and, this year alone, $\sim 40,000$ women will die from the disease. It affects about 1 in 7 women in the USA, and is the second most frequent cause of cancer death (1). Although much progress has been made in breast cancer treatment, metastatic breast cancer remains a generally incurable and fatal disease as $50 \%$ of patients die from it. Cytotoxic drug treatment is an important weapon against cancer. However, cancerous cells frequently develop drug resistance to these agents.

Breast cancer originates from genetic causes. Mutated or amplified genes are either inherited or occur sporadically. Hereditary breast cancer only accounts for about $10 \%$ of all breast cancer cases, and generally results from the lack of a tumor suppressor gene, as opposed to the gain of an oncogene. Approximately $45 \%$ of hereditary breast cancer is attributable to mutations in breast cancer-associated gene-1 (BRCA1), and an additional $45 \%$ is attributable to mutations in BRCA2 (1). Other tumor suppressor genes implicated in hereditary breast cancer include p53 and PTEN (174). The p53 tumor suppressor is a transcription factor involved in cell cycle regulation and DNA damage repair. Germline p53 mutation is present in $\sim 50 \%$ of patients with Li-Fraumeni syndrome (LFS), which is a multicancer familial syndrome that includes adrenocortical carcinoma, brain tumors, leukemia and osteosarcomas, in addition to early onset breast cancer. Breast cancer attributable to germline p53 mutation in the absence of LFS is rare. Germline PTEN mutation is present in $\sim 80 \%$ of patients with Cowden syndrome $(174,234)$. This disease, also known as multiple hamartoma syndrome, is another familial syndrome that includes many different types of cancer conditions, including early onset breast cancer. Mutations have been reported to occur at PTEN in breast cancer at varying frequencies $(5-21 \%)(235-239)$. Loss of heterozygosity is probably more common (30\%) (236). PTEN promoter methylation leads to low PTEN expression. In one study, 26\% of primary breast cancers had low PTEN levels, correlated with lymph node metastases and poor prognoses $(236,238,240,241)$. Mutations at certain residues of PTEN, which are associated with Cowden's disease, affect the ubiquitination of PTEN and prevent nuclear translocation. These mutations leave phosphatase activity intact (242). Inhibition of PTEN activity leads to centromere breakage and chromosome instability (243). PTEN therefore has diverse activities, and the disruption of PTEN activity by various genetic mechanisms could have far-reaching effects on different processes affecting the sensitivity of breast cancers to various therapeutic approaches.

Sporadic breast cancer accounts for the remaining $90 \%$ of all breast cancer cases. The PI3K p110 catalytic subunit is mutated in $\sim 25 \%$ of breast cancer specimens, with the mutations frequently resulting in the activation of its kinase activity $(202-205,239,244)$. Somatic mutation of p53 is associated with many cancers, and is present in $\sim 20 \%$ of sporadic breast cancer cases. In contrast, somatic mutation of BCRA1 or BCRA2 is rare in breast cancer patients. Another important cause of sporadic breast cancer is the amplification/ overexpression of HER2, which occurs in $20-30 \%$ of breast cancer cases. This gene encodes human epidermal growth factor (EGF) receptor-2 (HER2 a.k.a., c-ErbB-2), which is a receptor tyrosine kinase. The expression and activity of downstream signal transduction cascades, such as the Raf/MEK/ERK and PI3K/Akt pathways, changes as a result of these mutations. ERK and Akt are frequently activated in breast cancer specimens $(239,245)$. Consequently, the Raf/MEK/ERK and PI3K/Akt pathways are therapeutic targets in breast cancer.

The association of the genes that regulate signal transduction pathways with breast cancer implies that the pathways play an important role in the disease. Perhaps the best example of this is the association of HER2 gene amplification with breast cancer. While a normal breast cell possesses 20,00050,000 HER2 molecules, amplification of this gene can increase levels of HER2 to up to 2,000,000 molecules per cell $(129,246)$. The overexpression of HER2 in breast cancer is linked to comedo forms of ductal carcinoma in situ and occurs in $\sim 90 \%$ of these cases. HER 2 overexpression will lead to increased expression of both the Raf/MEK/ERK and PI3K/Akt pathways.

We have observed that ERK is activated after tamoxifen treatment of the MCF-7 breast cancer cell line. This is important with regards to the sensitivity of breast cancer cells to MEK inhibitors. ERK can phosphorylate and contribute to the inactivation of the tuberous sclerosis complex (TSC-2). Akt can also phosphorylate TSC-2 at a different residue, which leads to its inactivation. This leads to mTOR activation. 
Inhibition of TSC-2 phosphorylation by Raf/MEK and PI3K/ Akt inhibitors may make cells more sensitive to chemo- and hormonal therapy.

Activated Akt is furthermore often upregulated in breast cancer cells, and its overexpression is associated with a poor prognosis. However, this may actually render the breast cancer cells sensitive to Akt, as well as to downstream mTOR inhibitors. The formation of the rapamycin-sensitive mTORC1 complex [consisting of mTOR, regulatory-associated protein of mTOR (Raptor) and mLST8] in drug-resistant breast cancer cells that overexpress activated Akt may be different than in drug sensitive breast cells that do not overexpress activated Akt. In cells which express activated Akt, the Akt should phosphorylate TSC-2 and result in its inactivation. The mTORC1 complex is formed and downstream p70S6K and 4E-BP1 are phosphorylated, allowing the disassociation of eIF-4E, ribosome biogenesis and protein synthesis. In contrast, in the absence of Akt and ERK activation, this complex should not be formed. Rapamycin targets this complex, hence breast cancer cells that constitutively express activated Akt are more sensitive to rapamycin than those which do not. In breast cells that do not, this complex should be transiently assembled after growth factor treatment. In contrast, the assembly of the rapamycin-insensitive mTORC2 complex [consisting of the rapamycin-insensitive companion of mTOR (Rictor), mTOR, mLST8] should be lower in cells that constitutively express activated Akt than in those that do not, as there is equilibrium between the mTORC1 and mTORC2 complexes. The significance of these complex biochemical signaling events is that drug-resistant breast cancer cells which overexpress activated Akt or lack PTEN expression have an Achilles heel with regards to therapeutic intervention, as they are highly sensitive to rapamycin treatment. Drug-resistant breast cancer may also be hypersensitive to Raf/MEK inhibitors, as ERK plays a critical role in the phosphorylation of TSC-2 and p70S6K.

\section{Aberrant regulation of apoptosis may contribute to breast cancer and subsequent drug resistance}

Cell death following cytotoxic drug treatment is generally apoptotic as opposed to necrotic. Many chemotherapeutic drugs induce apoptosis by activating the intrinsic cell death pathway, which involves cytochrome c release and the activation of the apoptosome-catalyzed caspase cascade. During apoptosis, activation of caspase family cysteine proteases occurs. Although, as discussed earlier, the various cytotoxic drugs differ in their mechanisms of action, each ultimately relies upon built-in apoptotic machinery to elicit cell death $(130,166,174,234,247,248)$. Caspase family cysteine proteases are responsible for the proteolytic cleavage of the carboxyl terminal of cellular proteins to aspartate residues.

In a study involving 46 breast cancer patients, 75\% lacked caspase 3 mRNA transcripts and protein expression (249). The MCF-7 cell line has a mutation in caspase 3 and is deficient in certain aspects of apoptosis. In this respect, MCF-7 cells are a stringent model for the investigation of breast cancer apoptosis (250). Caspase 9 can be activated in MCF-7 cells, which can result in the sequential activation of caspases 7 and 6 (251). Caspase 7 is activated by the apoptosome complex and forms a XIAP-caspase 7 complex. This XIAP-caspase 7 complex is more stable in MCF-7 cells due to the absence of functional caspase 3 . ERK activity maintains XIAP levels; however, the mechanism by which this occurs is unknown. Resistance to chemotherapeutic drugs induced by the Raf/MEK/ERK pathway may be due in part to prolonged XIAP and caspase 9 expression, which prevents caspase 7 from exerting its effects on apoptosis $(145,252)$. ERK phosphorylates caspase 9, inhibiting its activation. The negative regulation of the caspases by ERK represents a mechanism by which Raf/MEK/ERK pathway activation prevents apoptosis. Raf/MEK inhibitors may affect caspase 9 activation and XIAP levels, and promote the apoptosis of cancer cells.

\section{Therapeutic targeting of the Raf/MEK/ERK pathway}

Small molecule inhibitors, such as Imatinib, have proven effective in the treatment of CML and certain other cancers which proliferate in response to BCR-ABL (e.g., some ALLs) and for cancers which proliferate in response to mutant platelet-derived growth factor receptor (PDGF-R) and c-Kit genes $(49,234,239,253-255)$, such as gastro-intestinal stromal tumors. Lung carcinomas which have mutations in EGFR are sensitive to EGFR inhibitors $(51,246,256-260)$. Raf and MEK inhibitors have been developed, and some are in clinical trials $(174,234,239,254,261)$. We have determined that a consequence of doxorubicin treatment in breast, hematopoietic and prostate cancer cell lines is the induction of ERK (51). Eliminating the deleterious side-effect of these therapies with Raf and MEK inhibitors may enhance their ability to kill drug-resistant cancer. PI3K, PDK, Akt and mTOR inhibitors have been developed. mTOR inhibitors have been used for many years as immunosuppressive drugs in kidney transplant patients, but have as a side effect the inhibition of a negative feedback pathway, which can result in Akt activation (262). Bcl-2 inhibitors have been developed which suppress Bcl-2 and Bcl- $\mathrm{X}_{\mathrm{L}}$, but not Mcl-1 (263). MDM-2 inhibitors have been developed which enhance WT p53 stability and activity (264). These inhibitors may augment the effects of chemo-, radio- and hormonal-based breast cancer therapies. A diagram illustrating the sites of action and other inhibitors is presented in Fig. 4.

Raf inhibitors have been developed as well, and some are being evaluated in clinical trials. A few 'Raf' inhibitors (Sorafenib) are approved for the treatment of certain cancers (e.g., renal cell carcinoma) (265-269). Certain Raf inhibitors have been developed that are small molecule competitive inhibitors of the ATP-binding site of Raf protein. These (e.g., L-779,450, ZM 336372 or Bay 43-9006, a.k.a Sorafenib) bind the Raf kinase domain and therefore prevent its activity. Some may affect a single Raf isoform (e.g., Raf-1), others may affect similar Raf proteins (Raf-1 and A-Raf), while other pan-Raf inhibitors may affect all three Raf proteins (Raf-1, A-Raf and B-Raf). We have observed that the L-779,450 inhibitor suppresses the effects of A-Raf and Raf-1 more than the effects of B-Raf (269). Like many Raf inhibitors, L-779,450 is not specific for Raf; it also inhibits the closely-related p38 $8^{\mathrm{MAPK}}$. Likewise, Sorafenib inhibits other kinases besides Raf (e.g., VEGF-II Receptor, PDGF-R, Kit, Flt-3 and Fms) and is more appropriately referred to as a multi-kinase inhibitor. Knowledge of the particular Raf gene mutated or overexpressed in certain 


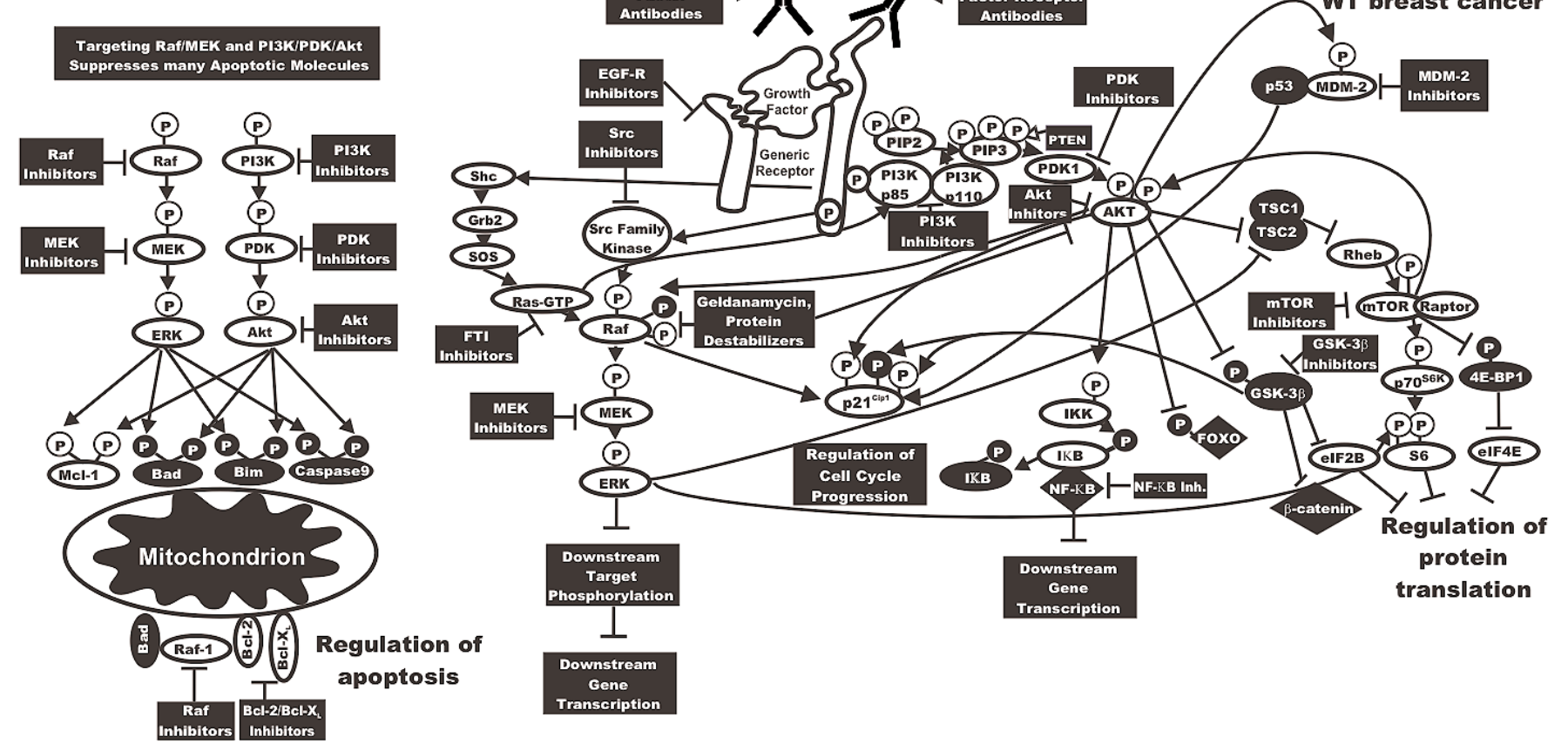

Figure 4. Targeting signal transduction pathways important in breast cancer. Potential sites of action of small molecular weight inhibitors and cytotoxic antibodies are indicated. In some cases, inhibitors will suppress growth, apoptotic and cell cycle regulatory pathways. This diagram serves to illustrate the concept that targeting Raf/MEK/ERK and PI3K/Akt pathways can have dramatic effects on many growth regulatory molecules. Proteins inactivated by S/T phosphorylation induced by the PI3K/Akt pathway are indicated with a white $\mathrm{P}$ in a black circle.

tumors may provide critical information regarding how to treat the patient, as some cancers which overexpress a particular Raf gene may be more sensitive to inhibition by agents which target that particular Raf protein. The inhibition of some Raf proteins might prove beneficial, while the suppression of others might, under certain circumstances, prove detrimental. Thus, the development of unique and broad-spectrum Raf inhibitors may prove useful in human cancer therapy.

Chaperonin proteins, such as 14-3-3 and Hsp90, regulate Raf activity (268), which is regulated by dimerization. These biochemical properties result in Raf activity being sensitive to drugs which block protein:protein interactions, such as geldanamycin (270). Geldanamycin and its 17-allyamino-17demethoxygeldanamycin (17-AAG) analogue are non-specific Raf inhibitors as they also affect the activity of many proteins which are stabilized by interaction with Hsp90. They are currently in clinical trials (271). We often think of a single Raf protein carrying out its biochemical activity. However, Raf isoforms dimerize with themselves and other Raf isoforms to become active. Drugs such as coumermycin, which inhibit Raf dimerization, and others such as geldanamycin, which prevent the interaction of Raf with Hsp90 and 14-3-3 proteins, suppress Raf activity. Geldanamycin has also been shown to be effective in suppressing the growth of non-small cell lung carcinoma (NSCLC) cells, which are gefitinib and erlotinib (both are EGFR inhibitors) resistant due to a second mutation in the EGFR (272). Furthermore, 17-AAG potentated the effects of paclitaxel in ovarian breast cancer lines that expressed high levels of activated Akt (273).

An alternative approach to targeting Raf is to prevent Raf activation by targeting the kinases (e.g., Src, PKC, PKA, PAK or Akt) and phosphatases (e.g., PP2A) involved in Raf activation. It can be predicted that some Src kinase inhibitors, such as Dasatinib, would inhibit Raf activation by suppressing Raf-1 and A-Raf, but not B-Raf, activation by Src. It is worth noting that some of these kinases normally inhibit Raf activation (Akt and PKA). A major limitation of this approach would be that these kinases and phosphatases could result in the activation or inactivation of other proteins, and would thus have other effects on cell physiology.

Currently, it is believed that MEK1 is not frequently mutated in human cancer. There was recently a report that MEK1 and MEK2, as well as B-Raf, are mutated in some patients with cardio-facio cutaneous syndrome (274). Aberrant expression of MEK1 is observed in many different cancers due to the activation of the Raf/MEK/ERK pathway by upstream kinases (e.g., BCR-ABL) and growth factor receptors (e.g., EGFR, Fms, Flt-3, PDGFR), as well as by other unknown mechanisms. Specific inhibitors to MEK have been developed [PD98059, U0126, PD184352 (a.k.a., CI1040), PD-0325901, Array MEK inhibitors (ARRY-142886 and others)] (261). Their successful development may be due to the relatively small number of phosphorylation sites on MEK involved in activation/inactivation. MEK inhibitors differ from most other kinase inhibitors as they do not compete with ATP binding. This confers a very high specificity (275). MEK inhibitors are very specific and do not inhibit many different protein kinases, including $\mathrm{p} 38^{\mathrm{MAPK}}$ and JNK (276). The crystal structures of MEK1 and MEK2 have been determined as ternary complexes with ATP and PD184352, and have revealed that both MEK1 and MEK2 have unique inhibitor binding sites located on a hydrophobic pocket adjacent to, but not overlapping, the ATP 
binding site (277). Furthermore, effective targeting of MEK1,2 is highly specific; ERK1,2 are its only well-described downstream targets. An advantage of targeting the Raf/MEK/ERK cascade is that it can be done without knowledge of the precise genetic mutation, which results in its aberrant activation. This is important as the nature of critical mutation(s), which leads to the malignant growth of at least $50 \%$ of AMLs and other cancers, is currently unknown. An advantage of targeting MEK is that the Raf/MEK/ERK pathway is a convergence point where a number of upstream signaling pathways can be blocked by the inhibition of a single kinase (MEK). MEK inhibitors, such as ARRY-142886 (AZD6244), are also being evaluated to treat hematopoietic malignancies, such as multiple myeloma (278-280).

To the best of our knowledge, no small molecular weight ERK inhibitors have been developed yet; however, inhibitors to ERK could prove very useful, as ERK can phosphorylate many targets (Rsk, c-Myc, Elk and at least 150 more). There are at least 2 ERK molecules regulated by the Raf/MEK/ ERK cascade, ERK1 and ERK2. Little is known about their different in vivo targets; however, it has been postulated that ERK2 has pro-proliferative effects, while ERK1 may have anti-proliferative effects (281). The development of specific inhibitors to ERK1 and ERK2 might eventually prove useful in the treatment of certain diseases.

\section{Combination therapies to enhance toxicity}

An approach that we have been investigating recently is to determine whether the inhibition of two signal transduction pathways is a more effective means to induce apoptosis than the inhibition of a single one. We have observed that the inhibition of the Raf/MEK/ERK and PI3K/Akt pathways is usually a more effective means, and that synergy between the two inhibitors is often observed. Many transformed cells have elevated Raf/MEK/ERK and/or PI3K/Akt signaling. These two pathways play prominent roles in the promotion of growth and the prevention of apoptosis. The PI3K/Akt pathway may be inhibited with PI3K (LY294002, PX-866), PDK1 (OSU-03012, Celecoxib), Akt (A-443654) inhibitors or downstream mTOR inhibitors, such as rapamycin and modified rapamycins (CCI-779, RAD001). Initially, mTOR inhibitors showed much promise, as PTEN is often deleted in various tumors. However, it has recently been determined that the mTOR pathway has a complicated feedback loop that actually involves the suppression of Akt, hence it can be predicted that mTOR inhibitors would activate Akt in some cells. Recent evidence has highlighted that mTOR can also be activated by Raf/MEK/ERK $(233,282)$. This may well be another relevant cross-talk between the Ras/Raf/MEK/ERK and the PI3K/Akt pathways, and might offer a further rationale for treatments combining drugs which inhibit both signaling networks. The effects of the combination of mTOR and Sorafenib are being evaluated in clinical trials to treat melanoma (283). The effects of combining EGFR and mTOR or mTOR and MEK inhibitors on cell cycle progression in the induction of apoptosis in kidney cells were examined, and synergistic effects were observed (284). The effects of EGFR and MEK inhibitors were enhanced by the addition of rapamycin, which resulted in enhanced $G_{1}$ arrest. Similar experiments have been performed on NSCLC with gefitinib and either the MEK inhibitor U0126 or the farnesyl transferase inhibitor SCH66336 (285).

In some cases, the precise gene responsible for driving the proliferation of the malignant cell is known (e.g., BCR-ABL in CML, EGFR in some cases of NSCLC, FLT-3 in some AMLs and B-Raf in melanoma). However, in many cancers there may be additional genes which are also critical to malignant transformation. Treatment of some of these diseases with specific kinase inhibitors is often effective; however, resistance to the inhibitors may develop due to further mutations in aberrant kinases, which often prevent the signal transduction inhibitor from inhibiting the altered kinase. In these novel 'drug-resistant' cases, additional therapeutic approaches are necessary. In some of these cases, it may be possible to inhibit the drug-resistant cells with novel inhibitors that will suppress the resistant oncoprotein or combinations of the MEK and PI3K/Akt inhibitors. We have observed that Imatinib-resistant hematopoietic cells (which have mutated BCR-ABL kinase) are sensitive to MEK inhibitors, a result which is not surprising as an Src inhibitor (Dasatinib) is used to inhibit them. These cells often have overexpression of an activated Src family kinase, such as Lyn, which likely acts by inducing the Raf/ MEK/ERK cascade.

Classic chemotherapy often remains the most used anticancer therapy for many different types of cancer treatment. Drugs such as doxorubicin and taxol are effective in the treatment of many cancers, although in some cases drug resistance does develop after prolonged treatment. Doxorubicin and taxol target cellular events, such as DNA replication and cell division, which are downstream of the targets of signal transduction pathway inhibitors. Thus, by combining classic chemotherapy with targeted therapy, it may be possible to enhance toxicity while lowering the effective concentrations of classic chemotherapeutics necessary for the complete elimination of a particular tumor.

We have investigated the effects of combining classic chemotherapy or hormonal therapy with signal transduction inhibitors in suppressing the growth of breast cancer cells. Treatment of breast cancer cells with MEK or mTOR inhibitors and either doxorubicin or tamoxifen resulted in a synergistic response documenting the effectiveness of classic chemotherapy with targeted therapy.

\section{Combining signal transduction inhibitors with anti- body, hormonal and chemotherapeutic-based therapies}

Recent studies have indicated that the effectiveness of certain antibody-based therapies (e.g., Herceptin, which targets HER2) may be greatly enhanced by the inclusion of mTOR inhibitors. These observations have been seen in preclinical studies performed in tissue culture and in xenograft models, and are being further evaluated in Phase II clinical trials (286). The cytotoxic effects of Herceptin can also be improved by the addition of an inhibitor such as Lapatinib, which targets both EGFR and HER2 (287).

The effectiveness of combining PI3K and mTOR inhibitors with the chemotherapeutic drug fludarabine has been examined in human leukemia cell lines (288). The combination of fludarabine and either PI3K or mTOR inhibitors resulted in 
increased apoptosis compared to what was observed following fludarabine treatment alone.

Rapamycin exerted synergistic effects when combined with paclitaxel, carboplatin and vinorelbine in certain responsive breast cancer lines in vitro (289). Rapamycin combined with paclitaxel resulted in a significant reduction in tumor volume in xenograft models when rapamycin sensitive tumors were examined. mTOR inhibitors also increased the chemosensitivity of cervical cancer cells to paclitaxel (290). The effects of rapamycin on sensitivity to paclitaxel are dependent on functional glycogen synthase kinase $3 \beta$ (GSK-3ß), as rapamycin induced toxicity in GSK-3ß WT cells but not in GSK-3ß null cells (291).

Combinations of rapamycin and the cell cycle checkpoint kinase (Chk1) inhibitor UCN-01 also resulted in a synergistic induction of apoptosis in human leukemic cells, regulated by the Raf/MEK/ERK, Akt and JNK signal transduction pathways (292). Coadministration of UCN-01 and rapamycin reduced the levels of Mcl-1, Bcl- $\mathrm{X}_{\mathrm{L}}$, cyclin D1 and p34 ${ }^{\mathrm{cdc} 2}$. Similar studies were performed with the farnesyl-transferase inhibitor L744832 and UCN-01, which also revealed a synergistic interaction in terms of the induction of apoptosis and the interruption of both Akt and MEK/ERK pathways and the activation of SEK1/JNK (293). L744832 blocked the induction of ERK normally stimulated by UCN-01.

Novel PI3K inhibitors have been developed. PWT-458 is a novel pegylated-17-hydroxywortmannin which inhibits PI3K and has been shown to suppress glioma, NSCLC and renal cell carcinoma in xenograft models (294). PWT-458 augmented the anticancer effects of paclitaxel and pegylated rapamycin in certain xenograft models.

The PI3K inhibitor LY294002 has been shown to block drug export from drug-resistant colon carcinoma cells overexpressing MRP-1 (295). Furthermore, combining the PI3K inhibitor with doxorubicin resulted in enhanced apoptosis, while combining doxorubicin with the MEK inhibitor did not.

Perifosine is an oral bioactive novel alkylphospholipid that inhibits Akt. Perifosine enhanced dexamethasome, doxorubicin and melphalan, and bortezomib induced multiple myeloma cytotoxicity (296). Furthermore, perifosine synergistically increased the effects of etoposide on the induction of apoptosis in human T-ALL cells (297). Additional Akt inhibitors have been developed. An Akt inhibitor developed by Abbott (A-443654) augmented the effectiveness of paclitaxel and rapamycin in suppressing tumor growth in xenograft models (298). Treatment of cells with this Akt inhibitor resulted in increased detection of activated Akt. Similar events are also observed with some MEK inhibitors; the incubation of cells with these resulted in increased levels of activated MEK but suppressed levels of activated ERK. There are two problems associated with the Abbott Akt inhibitor: increased toxicity and glucose secretion. There are also toxicity problems with the PI3K inhibitor LY294002, and pharmacological problems with some of the MEK inhibitors (CI1040) that prevent their usage in human cancer patients.

Suntinib was developed as a selective inhibitor of vascular endothelial growth factor-receptor (VEGFR). However, it has since been shown to have multiple targets. Suntinib sensitizes ovarian cancer cells to cisplatin via the suppression of nucleotide excision repair activity by inhibiting the expression of
G1 cell cycle checkpoint regulators (p53, p2 $1^{\text {Cip-1 }}, \mathrm{p} 27^{\text {Kip-1 }}$ and MDM2) (299). The chemosensitizing effects of Suntinib may be mediated by inhibiting $\mathrm{G}_{1}$ checkpoint control and upregulating the apoptotic response to cisplatin.

Multitargeted kinase inhibitors, such as Sorafenib and Sunitib, are being combined with an antibody (Bevacizumab) that targets the VEGF, and are being evaluated in clinical trials (300). Bevacizumab is also being combined with Erlotinib, an EGFR inhibitor, in a Phase II clinical trial for renal cell carcinoma patients. Furthermore, Beracizumab and mTOR inhibitors are being combined in clinical trials for renal cell carcinoma and melanoma patients (300).

\section{Enhancing the effects of Ras/Raf/MEK/ERK pathway inhibitors by combination therapy}

Although the precise targets of farnesyltransferase inhibitors remain controversial, the farnesyltransferase inhibitor R115777 (Zarnestra) was shown to result in disease stabilization in $64 \%$ of multiple myeloma patients in a Phase II clinical trial (301). Furthermore, R115777 was found to synergize with paclitaxel and docetaxel, but not with doxorubicin, 5-flurouracil, cisplatin, melphalan, mitoxantrone and dexamethasone.

A side-effect of some chemotherapeutic drugs, such as taxol, is the induction of the Raf/MEK/ERK pathway. Activation of this pathway can, under certain circumstances, promote proliferation and prevent apoptosis. Combining taxol treatment with MEK inhibitors has been observed to synergistically enhance apoptosis and inhibit tumor growth $(302,303)$. The synergistic effects of paclitaxel and MEK inhibitors are complex and not fully elucidated, but may be mediated in part by the inhibition of Bad phosphorylation at $\mathrm{S} 112$ by ERK (304).

Moreover, the cytotoxic effects of combinations of MEK inhibitors and paclitaxel may be specific for cells of certain origins and may depend on the levels of endogenous activated MEK/ERK present in those cells. Some studies with NSCLC cells that constitutively expressed activated MEK/ERK revealed no increase in paclitaxel-induced apoptosis upon treatment with a MEK inhibitor (305). In contrast, the addition of a dominant negative MEK gene to these cells potentiated paclitaxel-induced apoptosis.

MEK inhibitors have also been observed to affect cisplatin resistance in squamous cell carcinoma, implicating the Raf/ MEK/ERK pathway in their drug resistance (306). In neuroblastoma cells, cisplatin-induced apoptosis was associated with an increase in p53 and Bax proteins. Activated ERK1,2 levels were also increased earlier in these cells with cisplatin treatment. Culture of these cells with MEK inhibitors blocked apoptotic cell death, which prevented the cisplatin-induced accumulation of p53 and Bax (307).

MEK inhibitors have also been observed to synergize with arsenic trioxide (ATO) to induce apoptosis in acute promyelocytic leukemia (APL) and AML cells $(308,309)$. The p53-related gene p73 is a molecular target of the combined therapy. ATO modulates the expression of the $\mathrm{p} 73$ gene by inducing the pro-apoptotic and anti-proliferative 73 isoforms. p53 requires p63 and p73 for the induction of apoptosis in response to DNA-damaging drugs. p73 exists as a multiple transactivation competent (TA) of pro-apoptotic and anti- 
proliferative p73 $\mathrm{COOH}$-terminal splicing isoform $(\alpha, \beta, \gamma, \delta$,

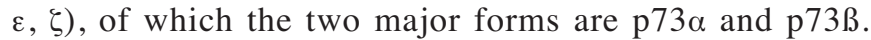
Dominant-negative $(\Delta \mathrm{N})$ p73 variants are expressed from a second promoter. These DN $\Delta \mathrm{Np} 73$ variants lack the aminoterminal transactivation domain, act as transrepressors of p53and p73-dependent transcription and have anti-apoptotic and pro-proliferative potential. Treatment of APL cells with the PD184352 MEK inhibitor reduced the level of $\Delta \mathrm{Np} 73$ and decreased the ATO-mediated upregulation of $\Delta \mathrm{Np} 73$, thus causing an increase in the $\mathrm{TA} / \Delta \mathrm{Np} 73$ ratio of dual-treated cells. High doses of ATO induced p53 accumulation in 11 of 21 patients. Combined treatment resulted in the induction of the pro-apoptotic p53/p73 target gene p53AIP1 (p53-regulated apoptosis-inducing protein 1) and greatly enhanced the apoptosis of treated cells (309). This study consequently documented the effectiveness of combining ATO with MEK inhibitors in the treatment of APL, and identified the molecular mechanism responsible for the observed synergism.

MEK inhibitors have been observed to synergize with UCN-01 and induce apoptosis in multiple myeloma cells (310). Part of the synergy may be due to UCN-01 inducing ERK activation, which is suppressed by the MEK inhibitor.

It should be pointed out that the combination of MEK inhibitors and a chemotherapeutic drug may not always result in a positive interaction; in some cases combination therapy results in an antagonistic response. For example, combining MEK inhibitors with betulinic acid, a drug lethal to melanoma cells, antagonized the effects that betulinic acid normally has on apoptosis (311). Furthermore, the precise timing of the addition of two drugs is important, as they may differentially affect cell cycle progression. Therefore, one drug may need to be added before the other for a synergynistic response to be observed, and perhaps to prevent an antagonistic one (297).

\section{Role of the Raf/MEK/ERK pathway in drug resistance to reactive oxygen intermediate-inducing cancer treatments}

Many cancer therapies induce the generation of oxygen radicals within cells. These therapies include treatments such as chemotherapeutic drugs and irradiation, and newer treatments such as photodynamic therapy (PDT). Doxorubicin, one of the chemotherapeutic drugs most effective against a wide range of cancers, works via two main mechanisms to exert anti-tumor effects and toxicity. It intercalates in the DNA and interferes with DNA polymerase by disrupting helicase activity (312). It also induces the production of free radicals and oxidative stress, which are involved in its anti-tumor effects $(313,314)$. The generation of oxygen radicals is important for the therapeutic effectiveness of doxorubicin, because scavenging reactive oxygen intermediates result in decreased cell killing by this drug (315).

The initial reactive oxygen species generated as a consequence of ionization radiation is $\mathrm{OH}^{-}$, which is short-lived and only diffuses about $4 \mathrm{~nm}$ before reacting. Secondary reactive oxygen species, produced in response to ionizing radiation, include $\mathrm{O}^{2-}$ and $\mathrm{H}_{2} \mathrm{O}_{2}$. Studies with fluorescent dyes have demonstrated the generation of reactive oxygen species within cells within 15 min after irradiation (316). Similar to doxorubicin, the generation of oxygen radicals is important for the therapeutic effectiveness of radiation therapy because scavenging reactive oxygen intermediates results in decreased cell killing in response to radiation (317).

PDT is a three-component treatment used in cancer cases (318) that requires a photosensitizer, molecular oxygen and a laser of a wavelength matching the absorption spectrum of the photosensitizer (porphyrins and porphyrin-related compounds). When a porphyrin molecule absorbs light, it can transform an oxygen molecule to an activated state. Similar to doxorubicin and irradiation, PDT also requires the production of oxygen radicals to mediate some of its anti-tumor effects (319). Thus, three well-known cancer treatments result in the generation of reactive oxygen intermediates. These same three treatments have also been shown to lead to the activation of ERK1,2 (320-323).

The Raf/MEK/ERK signaling pathway can play an adaptive role in protecting cells from oxidative stress (324). In a nonmalignant murine alveolar epithelial cell line, blocking MEK activation using the MEK inhibitor U0126 prevents hypoxiainduced Nrf2 upregulation (324). Deletion of ASK1 protects cells from oxidant-induced cell death, but not from death receptor-induced apoptosis (325). Conversely, hydrogen peroxide is capable of inducing apoptosis in cardiomyocytes, which can be increased in MEKK1 negative cells (326). The deletion of ASK1 protects against hydrogen peroxide-induced apoptosis in fibroblasts and also prevents prolonged p38 activation, suggesting an apoptotic role for $\mathrm{p} 38$ in response to oxidative stress (327). Ras activation and subsequent signaling via Rho can also activate this pathway, as does ligation of the TNF receptor (328-331). Redox activation of ERK5/BMK1 exhibits an anti-apoptotic effect (332). U0126 and PD98059 are also reported to inhibit the activity of MEK5, the MAPKK involved in ERK5/BMK1 activation (332-335). These inhibitors decreased PC12 cell viability in response to hydrogen peroxide treatment. This decrease in cell viability occurred when the ERK5/BMK1 protein was completely downregulated using siRNA, suggesting that the effects of U0126 and PD98059 were mediated in part via the ERK5/BMK1 pathway (332). These data indicate the potential for both the ERK $1 / 2$ and ERK5/BMK pathways to promote treatment resistance to currently-used reactive oxygen intermediate-inducing cancer treatments.

\section{Conclusions}

A variety of anticancer agents have been observed to extend survival in breast cancer patients. Novel drugs for the treatment of breast cancer patients will undoubtedly become available in the near future. Additional therapeutic options include radiation and surgery. The large number of choices available underscore the need to identify the optimal treatment for each individual breast cancer patient. It is likely that the selection of breast cancer therapy will increasingly depend on molecular features. Expression of ER $\alpha$ and HER2 are but two of the many characteristics that may impact breast cancer treatment decisions in the future.

Over the past 25 years, there has been much progress in elucidating the involvement of the Ras/Raf/MEK/ERK cascade in promoting normal cell growth and regulating apoptosis, and in understanding the etiology of human neoplasia and the induction of chemotherapeutic drug resistance. From initial 
seminal studies which shed light on the oncogenes present in avian and murine oncogenes, we learned that ErbB, Fms, Ras, Src, Abl, Raf, Fos, Ets and NF-кB (Rel) were originally cellular genes which were captured by retroviruses. Biochemical studies continue to elucidate the roles that these cellular and viral oncogenes have in cellular transformation. We have learned that many of these oncogenes are connected to the Ras/ Raf/MEK/ERK pathway, and either feed into this pathway (e.g., BCR-ABL, ErbB, Fms) or are downstream targets that regulate gene expression (e.g., Fos, Ets and NF-кB).

The Ras/Raf/MEK/ERK pathway has what often appears to be conflicting roles in cellular proliferation, differentiation and the prevention of apoptosis. Classical studies indicated that Ras/Raf/MEK/ERK can promote proliferation and malignant transformation, in part due to the stimulation of cell growth, and at the same time prevent apoptosis. Furthermore, an often overlooked aspect of Raf/MEK/ERK is its effects on cytokine and growth factor gene transcription, which can stimulate proliferation. The latest 'hot' area of the Ras/Raf/MEK/ERK pathway is the discovery of B-Raf mutations in human cancer, which can promote proliferation and transformation (116). The development and characterization of B-Raf inhibitors is a key research area in the pipeline for many pharmaceutical companies.

It was initially thought that Raf-1 was the most important Raf isoform. It was certainly the earliest-studied one, with homologous genes present in both murine and avian transforming retroviruses. Originally, it was shown that Raf-1 was ubiquitously expressed, indicating a more general and important role for it, while B-Raf and A-Raf had more limited patterns of expression. However, it is now believed that B-Raf is the more important activator of the Raf/MEK/ERK cascade and that, in some cases, Raf-1 activation may require B-Raf. However, Raf-1 has reared its head again in the field of cancer, thanks to the recent discovery that there are mutant Raf-1 alleles in certain breast cancer therapy-induced t-AMLs that are transmitted in a Mendelian fashion (117). The role of A-Raf remains poorly defined, yet it is an interesting isoform. It is the weakest Raf kinase, yet it can stimulate cell cycle progression and proliferation without the negative effects on cell proliferation that B-Raf and Raf- 1 can exert. It should be remembered that, under certain conditions, the hyperactivation of B-Raf and Raf-1 can promote cell cycle arrest (51). Thus, fine-tuning these mutations will probably influence whether cell cycle arrest or malignant transformation occurs.

The activation of the Raf proteins is very complex, as there are many phosphorylation sites on Raf. Phosphorylation at different sites can lead to either activation or inactivation. Clearly, there are many kinases and phosphatases which regulate Raf activity, and the state of phosphorylation determines whether Raf is active or inactive. While the kinases involved in the regulation of the Raf/MEK/ERK pathway have been extensively studied, there is but very limited knowledge of the specific phosphatases involved in these regulatory events.

Raf-1 has many roles which are apparently independent of downstream MEK/ERK. Some of these functions occur at the mitochondria and are intimately associated with the prevention of apoptosis. Raf-1 may function as a scaffolding molecule to inhibit the activity of kinases, which promote apoptosis. Thus, the development of Raf inhibitors may prove useful in the suppression of some of these non-MEK/ERK mediated events.

The Raf/MEK/ERK pathway is both positively [Hsp90, kinase suppressor of Ras (KSR), MEK partner-1 (MP-1)] and negatively (RKIP, 14-3-3) regulated by its association with scaffolding proteins. The expression of some of the scaffolding proteins is altered in some human cancers (e.g., RKIP). Some of these scaffolding proteins (e.g., Hsp90) are being evaluated as potential therapeutic targets (geldanamycin). The potential roles of Hsp90 in stabilizing activated forms of Raf are intriguing, and may allow the evolution of activated mutant forms of Raf.

The Raf/MEK/ERK pathway is intimately linked to the PI3K/PTEN/Akt pathway, both of which can be regulated by Ras. Furthermore, in some cell types Raf activity is negatively regulated by Akt, indicating a cross-talk between the two pathways. Both pathways may result in the phosphorylation of many downstream targets, and impose themselves on the regulation of cell survival and proliferation. Thus, the development of strategies to inhibit the pathways may be clinically important. These pathways phosphorylate many key proteins involved in apoptosis (e.g., Bad, Bim, Mcl-1, caspase 9, ASK-1 and others), which serves to alter their activities and subcellular localization. The phosphorylation events mediated by the Raf/MEK/ERK and PI3K/Akt pathways are associated with the prevention of apoptosis. In contrast JNK, which is another MAPK, also phosphorylates many of these molecules; these phosphorylation events often have effects opposite to those elicited by the Raf/MEK/ERK and PI3K/Akt pathways.

Ras and Raf mutations may not always have similar outcomes. For example, it could be predicted that a Ras mutation would activate both the Raf/MEK/ERK and PI3K/Akt pathways, with activation of $\mathrm{PI} 3 \mathrm{~K} / \mathrm{Akt}$ resulting in the suppression of Raf/MEK/ERK. However, mutation at either B-Raf or Raf-1 results only in the activation of Raf/MEK/ ERK. Thus, depending on the particular cancer and biological effect targeted, it is appropriate to develop Ras, Raf and MEK inhibitors.

Although we often think of the phosphorylation of these molecules as being associated with the prevention of apoptosis and the induction of gene transcription, this view is oversimplified. For example, in certain situations the Raf/MEK/ ERK pathway may be inhibited. In such cases, the phosphorylation of Bad and CREB, normally mediated by the Raf/ MEK/ERK cascade, which is associated with the prevention of apoptosis, is suppressed. Likewise, it is important to remember that, at some protein residues, phosphorylation results in enhanced activity, whereas at others it results in decreased activity. For example, thr phosphorylation of Bim by JNK is associated with the promotion of apoptosis, while the phosphorylation of Bim by the Raf/MEK/ERK or PI3K/Akt pathways is associated with the prevention of apoptosis.

A consequence of diverse cancer therapies (e.g., chemotherapy, radiation therapy, photodynamic therapy) is the induction of the Raf/MEK/ERK pathway, which may in some cases provide a survival function. The mechanism of induction of these pathways may in part be in response to ROS generated by the different therapies. Thus, in some cases it may be appropriate to combine these conventional therapies with 
small molecular weight inhibitors which target the Raf/MEK/ ERK pathway.

Although it has been known for many years that the Raf/ MEK/ERK pathway can affect cell cycle arrest, differentiation and senescence, these are probably some of the least studied research areas in the field. This is due to the often cell lineagespecific effects that must be evaluated in each cell type. An intriguing aspect of human cancer therapy is that, in some cases, stimulation of the Raf/MEK/ERK pathway may be requried to promote terminal differentiation, while in other types of malignant cancer cells, which proliferate in response to Raf/MEK/ERK activity, inhibition of the Raf/MEK/ERK pathway may be required to suppress proliferation. Thus, we must be flexible in dealing with the Raf/MEK/ERK pathway and, as we learn more, our conceptions will continue to change.

\section{Acknowledgements}

L.S.S., R.A.F. and J.A.M. were supported in part by a grant from the NIH (R01098195). A.B. was supported in part by a grant from the Associazione Italiana Ricerca sul Cancro (AIRC regional grant). A.M.M. was supported in part by a grant from the CARISBO Foundation, and from the Progetti Strategici Università di Bologna EF2006.

\section{References}

1. Centers for Disease Control and Prevention: Cancer: symptoms of breast cancer. Atlanta, GA, Centers for Disease Control and Prevention, http://www.cdc.gov/cancer/breast/basic_info/ symptoms.htm, 2006.

2. Jemal A, Tiwari RC, Murray T, Ghafoor A, Samuels A, Ward E, Feuer EJ and Thun MJ: Cancer statistics. CA Cancer J Clin 54: 8-29, 2004.

3. Meyn RE, Stephens LC, Hunter NR and Milas L: Induction of apoptosis in murine tumors by cyclophosphamide. Cancer Chemother Pharmacol 33: 410-414, 1994.

4. Schwartz PS and Waxman DJ: Cyclophosphamide induces caspase 9-dependent apoptosis in 9L tumor cells. Mol Pharmacol 60: 1268-1279, 2001 .

5. Goodman MF, Bessman MJ and Bachur NR: Adriamycin and daunorubicin inhibition of mutant T4 DNA polymerase. Proc Natl Acad Sci USA 71: 1193-1196, 1974

6. Goodman MF, Lee GM and Bachur NR: Adriamycin interactions with T4 DNA polymerase. Two modes of templatemediated inhibition. J Biol Chem 252: 2670-2674, 1977.

7. Tewey KM, Rowe TC, Yang L, Halligan BD and Liu LF: Adriamycin-induced DNA damage mediated by mammalian DNA topoisomerase II. Science 226: 466-468, 1984.

8. Capranico G, Kohn KW and Pommier Y: Local sequence requirements for DNA cleavage by mammalian topoisomerase II in the presence of doxorubicin. Nucleic Acids Res 18: 6611-6619, 1990.

9. Tsai-Pflugfelder M, Liu LF, Liu AA, Tewey KM, Whang-Peng J, Knutsen T, Huebner K, Croce CM and Wang JC: Cloning and sequencing of cDNA encoding human DNA topoisomerase II and localization of the gene to chromosome region 17q21-22. Proc Natl Acad Sci USA 85: 7177-7181, 1988.

10. Chung TDY, Drake FH, Tan KB, Per SR, Crooke ST and Mirabelli CK: Characterization and immunological identification of cDNA clones encoding two human DNA topoisomerase II isozymes. Proc Natl Acad Sci USA 86: 9431-9435, 1989

11. Jenkins JR, Ayton P, Jones T, Davies SL, Simmons DL, Harris AL, Sheer D and Hickson ID: Isolation of cDNA clones encoding the $B$ isozyme of human DNA topoisomerase II and localisation of the gene to chromosome 3p24. Nucleic Acids Res 20: 5587-5592, 1992.

12. Davies SL, Jenkins JR and Hickson ID: Human cells express two differentially spliced forms of topoisomerase IIß mRNA. Nucleic Acids Res 21: 3719-3723, 1993.
13. Järvinen TAH, Tanner M, Rantanen V, Bärlund M, Borg $\AA$, Grénman S and Isola $\mathrm{J}$ : Amplification and deletion of topoisomerase II $\alpha$ associate with ErbB-2 amplification and affect sensitivity to topoisomerase II inhibitor doxorubicin in breast cancer. Am J Pathol 156: 839-847, 2000.

14. Schiff PB and Horwitz SB: Taxol stablizes microtubules in mouse fibroblast cells. Proc Natl Acad Sci USA 77: 1561-1565, 1980.

15. Kumar N: Taxol-induced polymerization of purified tubulin. Mechanism of action. J Biol Chem 256: 10435-10441, 1981.

16. Rowinsky EK, Donehower RC, Jones RJ and Tucker RW: Microtubule changes and cytotoxicity in leukemic cell lines treated with Taxol. Cancer Res 48: 4093-4100, 1988.

17. Hudziak RM, Lewis GD, Winget M, Fendly BM, Shepard HM and Ullrich A: p $185^{\text {HER2 }}$ monoclonal antibody has antiproliferative effects in vitro and sensitizes human breast tumor cells to tumor necrosis factor. Mol Cell Biol 9: 1165-1172, 1989.

18. Carter P, Presta L, Gorman CM, Ridgway JBB, Henner D, Wong WLT, Rowland AM, Kotts C, Carver ME and Shepard HM: Humanization of an anti-p $185^{\mathrm{HER} 2}$ antibody for human cancer therapy. Proc Natl Acad Sci USA 89: 4285-4289, 1992.

19. Vogel CL, Cobleigh MA, Tripathy D, Gutheil JC, Harris LN, Fehrenbacher L, Slamon DJ, Murphy M, Novotny WF, Burchmore M, Shak S, Stewart SJ and Press M: Efficacy and safety of trastuzumab as a single agent in first-line treatment of HER2-overexpressing metastatic breast cancer. J Clin Oncol 20: 719-726, 2002.

20. Borgna JL and Rochefort H: Hydroxylated metabolites of tamoxifen are formed in vivo and bound to estrogen receptor in target tissues. J Biol Chem 256: 859-868, 1981.

21. Walter P, Green S, Greene G, Krust A, Bornert JM, Jeltsch JM, Staub A, Jensen E, Scrace G, Waterfield M and Chambon P: Cloning of the human estrogen receptor cDNA. Proc Natl Acad Sci USA 82: 7889-7893, 1985.

22. Green S, Walter P, Kumar V, Krust A, Bornert JM, Argos P and Chambon P: Human oestrogen receptor cDNA: sequence, expression and homology to v-erb-A. Nature 320: 134-139, 1986.

23. Greene GL, Gilna P, Waterfield M, Baker A, Hort Y and Shine J: Sequence and expression of human estrogen receptor complementary DNA. Science 231: 1150-1154, 1986.

24. Mosselman S, Polman J and Dijkema R: ERß: identification and characterization of a novel human estrogen receptor. FEBS Lett 392: 49-53, 1996.

25. Moore JT, McKee DD, Slentz-Kesler K, Moore LB, Jones SA, Horne EL, Su J-L, Kliewer SA, Lehmann JM and Willson TM: Cloning and characterization of human estrogen receptor $B$ isoforms. Biochem Biophys Res Commun 247: 75-78, 1998.

26. Ogawa S, Inoue S, Watanabe T, Orimo A, Hosoi T, Ouchi Y and Muramatsu M: Molecular cloning and characterization of human estrogen receptor ßcx: a potential inhibitor of estrogen action in human. Nucleic Acids Res 26: 3505-3512, 1998.

27. Shoda T, Hirata S, Kato J and Hoshi K: Cloning of the novel isoform of the estrogen receptor beta cDNA (ERß isoform M cDNA) from the human testicular cDNA library. J Steroid Biochem Mol Biol 82: 201-208, 2002.

28. Cowley SM, Hoare S, Mosselman S and Parker MG: Estrogen receptors $\alpha$ and $\beta$ form heterodimers on DNA. J Biol Chem 272: 19858-19862, 1997.

29. Pace P, Taylor J, Suntharalingam S, Coombes RC and Ali S: Human estrogen receptor $\beta$ binds DNA in a manner similar to and dimerizes with estrogen receptor $\alpha$. J Biol Chem 272: 25832-25838, 1997.

30. Pettersson K, Grandien K, Kuiper GG and Gustafsson J-Å: Mouse estrogen receptor $\beta$ forms estrogen response elementbinding heterodimers with estrogen receptor $\alpha$. Mol Endocrinol 11: 1486-1496, 1997.

31. Ogawa S, Inoue S, Watanabe T, Hiroi H, Orimo A, Hosoi T, Ouchi Y and Muramatsu M: The complete primary structure of human estrogen receptor $\beta(\mathrm{hER} \beta)$ and its heterodimerization with ER $\alpha$ in vivo and in vitro. Biochim Biophys Res Commun 243: $122-126,1998$.

32. Dong L, Wang W, Wang F, Stoner M, Reed JC, Harigai M, Samudio I, Kladde MP, Vyhlidal C and Safe S: Mechanisms of transcriptional activation of bcl-2 gene expression by $17 ß-$ estradiol in breast cancer cells. J Biol Chem 274: 32099-32107, 1999.

33. Perillo B, Sasso A, Abbondanza C and Palumbo G: 17ß-estradiol inhibits apoptosis in MCF-7 cells, inducing bcl-2 expression via two estrogen-responsive elements present in the coding sequence. Mol Cell Biol 20: 2890-2901, 2000. 
34. Zhang G-J, Kimijima I, Onda M, Kanno M, Sato H, Watanabe T, Tsuchiya A, Abe R and Takenoshita S: Tamoxifen-induced apoptosis in breast cancer cells relates to down-regulation of bcl-2, but not bax and bcl- $\mathrm{X}_{\mathrm{L}}$, without alteration of $\mathrm{p} 53$ protein levels. Clin Cancer Res 5: 2971-2977, 1999.

35. Barkhem T, Carlsson B, Nilsson Y, Enmark E, Gustafsson Jand Nilsson S: Differential response of estrogen receptor $\alpha$ and estrogen receptor $\beta$ to partial estrogen agonists/antagonists. Mol Pharmacol 54: 105-112, 1998.

36. Bernstein L, Deapen D, Cerhan JR, Schwartz SM, Liff J, McGann-Maloney E, Perlman JA and Ford L: Tamoxifen therapy for breast cancer and endometrial cancer risk. J Natl Cancer Inst 91: 1654-1662, 1999

37. Bergman L, Beelen MLR, Gallee MPW, Hollema H, Benraadt J and van Leeuwen FE: Risk and prognosis of endometrial cancer after tamoxifen for breast cancer. Lancet 356: 881-887, 2000

38. Yoneda K, Tanji Y, Ikeda N, Miyoshi Y, Taguchi T, Tamaki Y and Noguchi S: Influence of adjuvant tamoxifen treatment on bone mineral density and bone turnover markers in post-menopausal breast cancer patients in Japan. Cancer Lett 186: 223-230, 2002.

39. Harvey JM, Clark GM, Osborne CK and Allred DC: Estrogen receptor status by immunohistochemistry is superior to the ligandbinding assay for predicting response to adjuvant endocrine therapy in breast cancer. J Clin Oncol 17: 1474-1481, 1999.

40. Chang J, Powles TJ, Allred DC, Ashley SE, Clark GM, Makris A, Assersohn L, Gregory RK, Osborne CK and Dowsett M: Biologic markers as predictors of clinical outcome from systemic therapy for primary operable breast cancer. J Clin Oncol 17: 3058-3063, 1999.

41. Chang J, Powles TJ, Allred DC, Ashley SE, Makris A, Gregory RK, Osborne CK and Dowsett M: Prediction of clinical outcome from primary tamoxifen by expression of biologic markers in breast cancer patients. Clin Cancer Res 6: 616-621, 2000.

42. Fisher B, Anderson S, Tan-Chiu E, Wolmark N, Wickerham DL, Fisher ER, Dimitrov NV, Atkins JN, Abramson N, Merajver S, Romond EH, Kardinal CG, Shibata HR, Margolese RG and Farrar WB: Tamoxifen and chemotherapy for axillary nodenegative, estrogen receptor-negative breast cancer: findings from National Surgical Adjuvant Breast and Bowel Project B-23. J Clin Oncol 19: 931-942,2001

43. Nabholtz JM, Buzdar A, Pollak M, Harwin W, Burton G, Mangalik A, Steinberg M and von Euler M: Anastrozole is superior to tamoxifen as first-line therapy for advanced breast cancer in postmenopausal women: results of a North American multicenter randomized trial. J Clin Oncol 18: 3758-3767, 2000.

44. Mouridsen H, Gershanovich M, Sun Y Pérez-Carrión R, Boni C, Monnier A, Apffelstaedt J, Smith R, Sleeboom HP, Jäenicke F, Pluzanska A, Dank M, Becquart D, Bapsy PP, Salminen E, Snyder R, Lassus M, Verbeek JA, Staffler B, Chaudri-Ross HA and Dugan M: Superior efficacy of letrozole versus tamoxifen as first-line therapy for postmenopausal women with advanced breast cancer: results of a phase III study of the International Letrozole Breast Cancer Group. J Clin Oncol 19: 2596-2606, 2001.

45. Mouridsen H, Gershanovich M, Sun Y, Pérez-Carrión R, Boni C, Monnier A, Apffelstaedt J, Smith R, Sleeboom HP, Jaenicke F, Pluzanska A, Dank M, Becquart D, Bapsy PP, Salminen E, Snyder R, Chaudri-Ross H, Lang R, Wyld P and Bhatnagar A: Phase III study of letrozole versus tamoxifen as first-line therapy of advanced breast cancer in postmenopausal women: analysis of survival and update of efficacy from the International Letrozole Breast Cancer Group. J Clin Oncol 21: 2101-2109, 2003.

46. Mouridsen H, Sun Y, Gershanovich M, Perez-Carrion R, Becquart D, Chaudri-Ross HA and Lang R: Superiority of letrozole to tamoxifen in the first-line treatment of advanced breast cancer: evidence from metastatic subgroups and a test of functional ability. Oncologist 9: 489-496, 2004.

47. Blalock WL, Weinstein-Oppenheimer C, Chang F, Hoyle PE, Wang X-Y, Algate PA, Franklin RA, Oberhaus SM, Steelman LS and McCubrey JA: Signal transduction, cell cycle regulatory, and anti-apoptotic pathways regulated by IL-3 in hematopoietic cells: possible sites for intervention with anti-neoplastic drugs. Leukemia 13: 1109-1166, 1999.

48. Lee JT Jr and McCubrey JA: The Raf/MEK/ERK signal transduction cascade as a target for chemotherapeutic intervention. Leukemia 16: 486-507, 2002.

49. Steelman LS, Pohnert SC, Shelton JG, Franklin RA, Bertrand FE and McCubrey JA: JAK/STAT, Raf/MEK/ERK, PI3K/Akt and BCR-ABL in cell cycle progression and leukemogenesis. Leukemia 18: 189-218, 2004.
50. McCubrey JA, Lee JT, Steelman LS, Blalock WL, Moye PW Chang F, Pearce M, Shelton JG, White MK, Franklin RA and Pohnert SC: Interactions between the PI3K and Raf signaling pathways can result in the transformation of hematopoietic cells. Cancer Detect Prev 25: 375-393, 2005.

51. McCubrey JA, Steelman LS, Chappell WH, Abrams SL, Wong EW, Chang F, Lehmann B, Terrian DM, Milella M, Tafuri A, Stivala F, Libra M, Basecke J, Evangelisti C, Martelli AM and Franklin RA: Roles of the Raf/MEK/ERK pathway in cell growth, malignant transformation and drug resistance. Biochim Biophys Acta 1773: 1263-1284, 2007.

52. Matsuguchi T, Salgia R, Hallek M, Eder M, Druker B, Ernst TJ and Griffin JD: Shc phosphorylation in myeloid cells is regulated by granulocyte macrophage colony-stimulating factor, interleukin-3 and steel factor and is constitutively increased by p210BCR/ABL. J Biol Chem 269: 5016-5021, 1994.

53. Inhorn RC, Carlesso N, Durstin M, Frank DA and Griffin JD: Identification of a viability domain in the granulocyte/macrophage colony-stimulating factor receptor beta-chain involving tyrosine-750. Proc Natl Acad Sci USA 92: 8665-8669, 1995.

54. Okuda K, Foster R and Griffin JD: Signaling domains of the beta $c$ chain of the GM-CSF/IL-3/IL-5 receptor. Ann NY Acad Sci 872: 305-313, 1999

55. Tauchi T, Boswell HS, Leibowitz D, Broxmeyer HE, Tauchi T, Boswell HS, Leibowitz D and Broxmeyer HE: Coupling between p210bcr-abl and Shc and Grb2 adaptor proteins in hematopoietic cells permits growth factor receptor-independent link to ras activation pathway. J Exp Med 179: 167-175, 1994.

56. Lanfrancone L, Pelicci G, Brizzi MF, Aronica MG, Casciari C, Giuli S, Pegoraro L, Pawson T, Pelicci PG and Arouica MG: Overexpression of Shc proteins potentiates the proliferative response to the granulocyte-macrophage colony-stimulating factor and recruitment of Grb2/Sos and Grb2/p140 complexes to the beta receptor subunit. Oncogene 10: 907-917, 1995.

57. Karin M, Minden A, Lin A, McMahon M, Lange-Carter C, Derijard B, Davis RJ and Johnson GL: Differential activation of ERK and JNK mitogen-activated protein kinases by Raf-1 and MEKK. Science 266: 1719-1723, 1994.

58. Lange-Carter CA and Johnson GL: Ras-dependent growth factor regulation of MEK kinase in PC12 cells. Science 265: 1458-1461, 1994

59. Marais R, Light Y, Paterson HF and Marshall CJ: Ras recruits Raf-1 to the plasma membrane for activation by tyrosine phosphorylation. EMBO J 14: 3136-3145, 1995.

60. Xu S, Robbins D, Frost J, Dang A, Lange-Carter C and Cobb MH: MEKK1 phosphorylates MEK1 and MEK2 but does not cause activation of mitogen-activated protein kinase. Proc Natl Acad Sci USA 92: 6808-6812, 1995.

61. Marais R, Light Y, Paterson HF, Mason CS and Marshall CJ: Differential regulation of Raf-1, A-Raf and B-Raf by oncogenic ras and tyrosine kinases. J Biol Chem 272: 4378-4383, 1997.

62. Mason CS, Springer CJ, Cooper RG, Superti-Furga G, Marshall CJ and Marais R: Serine and tyrosine phosphorylations cooperate in Raf-1, but not B-Raf activation. EMBO J 18: 2137-2148, 1999.

63. Deng T and Karin M: c-Fos transcriptional activity stimulated by H-Ras-activated protein kinase distinct from JNK and ERK. Nature 371: 171-175, 1994

64. Davis RJ, Derijard B, Raingeaud J, Barrett T, Wu IH, Han J and Ulevitch RJ: Independent human MAP kinase signal transduction pathways defined by MEK and MKK isoforms. Science 267: 682-685, 1995

65. Xing J, Ginty DD and Greenberg ME: Coupling of the RasMAPK pathway to gene activation by Rsk2, a growth factor regulated CREB kinase. Science 273: 959-963, 1996.

66. Cardone MH, Roy N, Stennicke HR, Salvesen GS, Franke TF Stanbridge E, Frisch S and Reed JC: Regulation of cell death protease caspase- 9 by phosphorylation. Science 282: 1318-1321 1998

67. Coutant A, Rescan C, Gilot D, Loyer P, Guguen-Guillouzo C and Baffet G: PI3K-FRAP/mTOR pathway is critical for hepatocyte proliferation whereas MEK/ERK supports both proliferation and survival. Hepatology 36: 1079-1088, 2002.

68. Iijima Y, Laser M, Shiraishi H, Willey CD, Sundaravadivel B, Xu L, McDermott PJ and Kuppuswamy D: c-Raf/MEK/ERK pathway controls protein kinase C-mediated p70S6K activation in adult cardiac muscle cells. J Biol Chem 277: 23065-23075, 2002.

69. Allan LA, Morrice N, Brady S, Magee G, Pathak S and Clarke PR: Inhibition of caspase-9 by phosphorylation at Thr125 by ERK MAP kinase. Nat Cell Biol 5: 647-654, 2003. 
70. Blalock WL, Navolanic PM, Steelman LS, Shelton JG, Moye PW, Lee JT, Franklin RA, Mirza A, McMahon M, White MK and McCubrey JA: Requirement for the PI3K/Akt pathway in MEK1mediated growth and prevention of apoptosis: identification of an Achilles heel in leukemia. Leukemia 17: 1058-1067, 2003.

71. Wang CY, Bassuk AG, Boise LH, Thompson CB, Bravo R and Leiden JM: Activation of the granulocyte-macrophage colonystimulating factor promoter in $\mathrm{T}$ cells requires cooperative binding of Elf-1 and AP-1 transcription factors. Mol Cell Biol 14: 1153-1159, 1994.

72. Davis RJ: Transcriptional regulation by MAP kinases. Mol Reprod Dev 4: 459-467, 1995.

73. Thomas RS, Tymms MJ, McKinlay LH, Shannon MF, Seth A and Kola I: ETS1, NFkappaB and AP1 synergistically transactivate the human GM-CSF promoter. Oncogene 23: 2845-2855, 1997.

74. Robinson MJ, Stippec SA, Goldsmith E, White MA and Cobb MH: A constitutively active and nuclear form of the MAP kinase ERK2 is sufficient for neurite outgrowth and cell transformation. Curr Biol 21: 1141-1150, 1998.

75. McCubrey JA, May WS, Duronio V and Mufson A: Serine/ threonine phosphorylation in cytokine signal transduction. Leukemia 14: 9-21, 2000.

76. Aplin AE, Stewart SA, Assoian RK and Juliano RL: Integrinmediated adhesion regulates ERK nuclear translocation and phosphorylation of Elk-1. J Cell Biol 153: 273-282, 2001

77. Tresini M, Lorenzini A, Frisoni L, Allen RG and Cristofalo VJ: Lack of Elk-1 phosphorylation and dysregulation of the extracellular regulated kinase signaling pathway in senescent human fibroblast. Exp Cell Res 269: 287-300, 2001

78. Eblen ST, Catling AD, Assanah MC and Weber MJ: Biochemical and biological functions of the N-terminal, noncatalytic domain of extracellular signal-regulated kinase 2. Mol Cell Biol 21: 249-259, 2001.

79. Adachi T, Kar S, Wang M and Carr BI: Transient and sustained ERK phosphorylation and nuclear translocation in growth control. J Cell Physiol 192: 151-159, 2002.

80. Ponti C, Gibellini D, Boin F, Melloni E, Manzoli FA, Cocco L, Zauli $\mathrm{G}$ and Vitale M: Role of CREB transcription factor in c-fos activation in natural killer cells. Eur J Immunol 32: 3358-3365, 2002.

81. Fry TJ and Mackall CL: Interleukin-7: from bench to clinic. Blood 99: 3892-3904, 2002.

82. Deng X, Kornblau SM, Ruvolo PP and May WS Jr: Regulation of Bcl2 phosphorylation and potential significance for leukemic cell chemoresistance. J Natl Cancer Inst Monogr 28: 30-37, 2001.

83. Carter BZ, Milella M, Tsao T, McQueen T, Schober WD, Hu W, Dean NM, Steelman LS, McCubrey JA and Andreeff M: Regulation and targeting of anti-apoptotic XIAP in acute myeloid leukemia. Leukemia 17: 2081-2089, 2003.

84. Jia W, Yu C, Rahmani M, Krystal G, Sausville EA, Dent P and Grant S: Synergistic antileukemic interactions between 17 AAG and UCN-01 involve interruption of RAF/MEK- and AKTrelated pathways. Blood 102: 1824-1832, 2003.

85. Troppmair J and Rapp UR: Raf and the road to cell survival: a tale of bad spells, ring bearers and detours. Biochem Pharmacol 66: $1341-1345,2003$

86. Ley R, Balmanno K, Hadfield K, Weston C and Cook SJ: Activation of the ERK1/2 signaling pathway promotes phosphorylation and proteasome-dependent degradation of the $\mathrm{BH}$ only protein, Bim. J Biol Chem 278: 18811-18816, 2003.

87. Weston CR, Balmanno K, Chalmers C, Hadfield K, Molton SA, Ley R, Wagner EF and Cook SJ: Activation of ERK1/2 by deltaRaf-1:ER* represses Bim expression independently of the JNK or PI3K pathways. Oncogene 22: 1281-1293, 2003.

88. Domina AM, Vrana J, Gregory MA, Hann SR and Craig RW: MCL1 is phosphorylated in the PEST region and stabilized upon ERK activation in viable cells, and at additional sites with cytotoxic okadaic acid or taxol. Oncogene 23: 5301-5315, 2004.

89. Harada H, Quearry B, Ruiz-Vela A and Korsmeyer SJ: Survival factor-induced extracellular signal-regulated kinase phosphorylates BIM, inhibiting its association with BAX and proapoptotic activity. Proc Natl Acad Sci USA 101: 15313-15317, 2004.

90. Marani M, Hancock D, Lopes R, Tenev T, Downward J and Lemoine NR: Role of Bim in the survival pathway induced by Raf in epithelial cells. Oncogene 23: 2431-2441, 2004.

91. Gëlinas C and White E: BH3-only proteins in control: specificity regulates MCL-1 and BAK-mediated apoptosis. Genes Dev 19: 1263-1268, 2006
92. O'Neill E, Rushworth L, Baccarini M and Kolch W: Role of the kinase MST2 in suppression of apoptosis by the protooncogene Raf. Science 306: 2267-2270, 2004.

93. O'Neill EE, Matallanas D and Kolch W: Mammalian sterile 20-like kinases in tumor suppression: an emerging pathway. Cancer Res 65: 5485-5487, 2005.

94. Yang E, Zha J, Jockel J, Boise LH, Thompson CB and Korsmeyer SJ: Bad, a hetro-dimeric partner for Bcl-xL and Bcl-2 displaces Bax and promotes cell death. Cell 80: 285-291, 1995.

95.Pugazhenthi S, Miller E, Sable C, Young P, Heidenreich KA, Boxer LM and Reusch JE: Insulin-like growth factor-I induces Bcl-2 promoter through the transcription factor c-AMP-response element-binding protein. J Biol Chem 274: 27529-27535, 1999.

96. Wang JM, Chao JR, Chen W, Kuo ML, Yen JJ and YangYen HF: The anti-apoptotic gene Mcl-1 is upregulated by the phosphatidylinositol 3-kinase/Akt signaling pathway through a transcription factor complex containing CREB. Mol Cell Biol 19: 6195-6206, 1999.

97. Bonni A, Brunet A, West AE, Datta SR, Takasu MA and Greenberg ME: Cell survival promoted by the Ras-MAPK signaling pathway by transcription-dependent and independent mechanisms. Science 286: 1358-1362, 1999.

98.Pugazhenthi S, Nesterova A, Sable C, Heidenreich KA, Boxer LM, Heasley LE and Reusch JE: Akt/protein kinase B up-regulates Bcl-2 expression through cAMP-response elementbinding protein. J Biol Chem 275: 10761-10766, 2000.

99. Datta SR, Dudek H, Tao X, Masters S, Fu H, Gotoh Y and Greenberg MA: Akt phosphorylation of BAD couples survival signals to the cell-intrinsic death machinery. Cell 91: 231-241, 1997.

100.Harada H, Becknell B, Wilm M, Mann M, Huang LJS, Taylor SS, Scott JD and Korsmeyer SJ: Phosphorylation and inactivation of BAD by mitochondria-anchored protein kinase A. Mol Cell 3: 413-422, 1999.

101. Sunayama J, Tsuruta F, Masuyama N and Gotoh Y: JNK antagonizes Akt-mediated survival signals by phosphorylating 14-3-3. J Cell Biol 170: 295-304, 2005.

102. Wang K, Gross A, Waksman G and Korsmeyer SJ: Mutagenesis of the BH3 domain of BAX identifies residues critical for dimerization and killing. Mol Cell Biol 18: 6083-6089, 1998.

103. Nosaka T, Kawashima T, Misawa K, Ikuta K, Mui AL and Kitamura T: STAT5 as a molecular regulator of proliferation, differentiation and apoptosis in hematopoietic cells. EMBO J 18: 4754-4765, 1999.

104. Putcha GV, Le S, Frank S, Besirli CG, Clark K, Chu B, Alix S, Youle RJ, LaMarche A, Maroney AC and Johnson EM Jr: JNK-mediated BIM phosphorylation potentiates BAXdependent apoptosis. Neuron 8: 899-914, 2003

105. Ernst P, Fisher JK, Avery W, Wade S, Foy D and Korsmeyer SJ: Definative hematopoiesis requires the mixed-lineage gene. Dev Cell 6: 437-443, 2004.

106. She QB, Solit DB, Ye Q, O'Reillly KE, Lobo J and Rosen N: The BAD protein integrates survival signaling by EGFR/ MAPK and PI3K/Akt kinase pathways in PTEN-deficient tumor cells. Cancer Cell 8: 297-297, 2005.

107. Chen L, Willis SN, Wei A, Smith BJ, Fletcher JI, Hinds MG, Colman PM, Day CL, Adams JM and Huang DC: Differential targeting of prosurvival $\mathrm{Bcl}-2$ proteins by their $\mathrm{BH} 3$-only ligands allows complementary apoptotic function. Mol Cell 17 393-403, 2005.

108. Willis SN, Chen L, Dewson G, Wei A, Naik E, Fletcher JI, Adams JM and Huang DC: Proapoptotic Bak is sequestered by Mcl-1 and Bcl-xL, but not Bcl-2, until displaced by BH3-only proteins. Genes Dev 19: 1294-1305, 2005.

109. Qi XJ, Wildey GM and Howe PH: Evidence that Ser87 of BimEL is phosphorylated by Akt and regulates BimEL apoptotic function. J Biol Chem 281: 813-823, 2006

110. Vrana JA, Cleaveland ES, Eastman A and Craig RW: Inducerand cell type-specific regulation of anti-apoptotic MCL-1 in myeloid leukemia and multiple myeloma cells exposed to differentiation-inducing or microtubule-disrupting agents. Apoptosis 11: 1275-1288, 2006.

111.Inoshita S, Takeda K, Hatai T, Terada Y, Sano M, Hata J, Umezawa A and Ichijo H: Phosphorylation and inactivation of myeloid cell leukemia 1 by JNK in response to oxidative stress. J Biol Chem 277: 43730-43734, 2002.

112. Maurer U, Charvet C, Wagman AS, Dejardin E and Green DR: Glycogen synthase kinase-3 regulates mitochondrial outer membrane permeabilization and apoptosis by destabilization of MCL-1. Mol Cell 21: 749-760, 2006. 
113. Yu J and Zhang L: The transcriptional targets of $\mathrm{p} 53$ in apoptosis control. Biochem Biophys Res Commun 331: 851-858, 2005.

114. Flotho S, Valcamonica S, Mach-Pascual G, Schmahl L, Corral J, Ritterbach H, Hasle M, Arico A and Biondi CM: RAS mutations and clonality analysis in children with juvenile myelomonocytic leukemia (JMML). Leukemia 13: 32-37, 1999.

115. Stirewalt DL, Kopecky KJ, Meshinchi S, Appelbaum FR, Slovak ML, Willman CL and Radich JP: FLT3, RAS and TP53 mutations in elderly patients with acute myeloid leukemia. Blood 97: 3589-3595, 2001.

116. Garnett MJ and Marais R: Guilty as charged: B-Raf is a human oncogene. Cancer Cell 6: 313-319, 2004.

117.Zebisch A, Staber PB, Delavar A, Bodner C, Hiden K, Fischereder K, Janakiraman M, Linkesch W, Auner HW, Embergber W, Windpassinger C, Schimek MG, Hoefler G, Troppmair J and Sill H: Two transforming C-RAF germ-line mutations identified in patients with therapy-related acute myeloid leukemia. Cancer Res 166: 3401-3408, 2006.

118. Davies H, Bignell GR, Cox C, Stephens P, Edkins S, Clegg S, Teague J, Woffendin J, Garnett MJ, Bottomley W, Davis N, Dicks E, Ewing R, Floyd Y, Gray K, Hall S, Hawes R, Hughes J, Kosmidou V, Menzies A, Mould C, Parker A, Stevens C, Watt S, Hooper S, Wilson R, Jayatilake H, Gusterson BA, Cooper C, Shipley J, Hargrave D, PritchardJones K, Maitland N, Chenevix-Trench G, Riggins GJ, Bigner DD, Palmieri G, Cossu A, Flanagan A, Nicholson A, Ho JW, Leung SY, Yuen ST, Weber BL, Seigler HF, Darrow TL, Paterson H, Marais R, Marshall CJ, Wooster R, Stratton MR and Futreal PA: Mutations of the BRAF gene in human cancer. Nature 417: 949-954, 2002.

119.Fransen K, Klinntenas M, Osterstrom A, Dimberg J, Monsteis HJ and Soderkvist P: Mutation analysis of the B-Raf, A-Raf and Raf-1 genes in human colorectal adenocarcinomas. Carcinogenesis 25: 527-533, 2004.

120.Libra L, Malaponte G, Navolanic PM, Gangemi P, Bevelacqua V, Proietti L, Bruni B, Stivala F, Mazzarino MC, Travali S and McCubrey JA: Analysis of BRAF mutation in primary and metastatic melanoma. Cell Cycle 4: 968-970, 2006.

121. Wan PT, Garnett MJ, Ros SM, Lee S, Niculescu-Duvaz D, Good VM, Jones CM, Marshall CJ, Springer CJ, Barford D and Marais R: Mechanism of activation of the Raf-MEK signaling pathway by oncogenic mutations of B-Raf. Cell 116: 856-867, 2004.

122. Busca R, Abbe P, Mantous F, Aberdam E, Peyssonnaux C, Eychene A, Ortonne JP and Ballot R: Ras mediates the cAMPdependent activation of extracellular signal-regulated in melanocytes. EMBO J 19: 2900-2910, 2000.

123. Garnett MJ, Rana S, Paterson H, Barford D and Marais R: Wildtype and mutant B-RAF activate C-RAF through distinct mechanisms involving heterodimerization. Mol Cell 20: 963-969, 2005.

124. Rushworth LK, Hindley AD, O'Neil E and Kolch W: Regulation and role of Raf-1.B-Raf heterodimerization. Mol Cell Biol 26: 2262-2272, 2006.

125. Rajagopalan H, Bardelli A, Lengauer C, Kinzler KN, Vogelstein B and Velculescu VE: Tumorigenesis: Raf/Ras oncogenes and mismatch-repair status. Nature 418: 934, 2002.

126. Yuen ST, Davies H, Chan TL, Ho JW, Bignell GR, Cox C, Stephens P, Edkins S, Tsui WW, Chan AS, Futreal PA, Stratton MR, Wooster R and Leung SY: Similarity of the phenotypic patterns associated with B-Raf and KRAS mutations in colorectal neoplasia. Cancer Res 62: 6451-6455, 2002.

127. Drexler HG: Expression of the FLT-3 receptor and response to FLT3 ligand by leukemic cells. Leukemia 10: 588-599, 1996.

128. Rao P and Mufson RA: A membrane proximal domain of the human interleukin-3 receptor beta c subunit that signals DNA synthesis in NIH 3T3 cells 1995 specifically binds a complex of Src and Janus family tyrosine kinases and phosphatidylinositol 3-kinase. J Biol Chem 270: 6886-6893, 1995.

129. Chang F, Lee JT, Navolanic PM, Steelman LS, Shelton JG, Blalock WL, Franklin RA and McCubrey JA: Involvement of PI3K/Akt pathway in cell cycle progression, apoptosis and neoplastic transformation: a target for cancer chemotherapy. Leukemia 17: 590-603, 2003.

130. Chang F, Steelman LS, Shelton JG, Lee JT, Navolanic PN, Blalock WL, Franklin RA and McCubrey JA: Regulation of cell cycle progression and apoptosis by the Ras/Raf/MEK/ERK pathway. Int J Oncol 22: 469-480, 2003.

131. Songyang Z, Baltimore D, Cantley LC, Kaplan DR and Franke TF: Interleukin 3-dependent survival by the Akt protein kinase. Proc Natl Acad Sci USA 94: 11345-11350, 1997.
132. Troussard AA, Mawji NM, Ong C, Mui A, St-Arnaud R and Dedhar S: Conditional knock-out of integrin-linked kinase demonstrates an essential role in protein kinase B/Akt activation. J Biol Chem 278: 22374-22378, 2003.

133. Xu Z, Ma DZ, Wang LY, Su JM and Zha XL: Transforming growth factor-beta1 stimulated protein kinase B serine-473 and focal adhesion kinase tyrosine phosphorylation dependent on cell adhesion in human hepatocellular carcinoma SMMC-7721 cells. Biochim Biophys Res Commun 312: 388-396, 2003.

134. Persad S and Dedhar S: The role of integrin-linked kinase (ILK) in cancer progression. Cancer Metastasis Rev 22: 375-384, 2003.

135. Kumar AS, Naruszewicz I, Wang P, Leung-Hagesteijn C and Hannigan GE: ILKAP regulates ILK signaling and inhibits anchorage-independent growth. Oncogene 23: 3454-3461, 2004.

136. Del Peso L, Gonzalez-Garcia M, Page C, Herrera R and Nunez G: Interleukin-3-induced phosphorylation of BAD through the protein kinase Akt. Science 278: 687-689 1997.

137. Scheid MP and Duronio V: Dissociation of cytokine-induced phosphorylation of Bad and activation of PKB/akt: involvement of MEK upstream of Bad phosphorylation. Proc Natl Acad Sci USA 95: 7439-7444, 1998.

138. Nakae J, Park BC and Accili D: Insulin stimulates phosphorylation of the forkhead transcription factor FKHR on serine 253 through a Wortmannin-sensitive pathway. J Biol Chem 274: 15982-15985, 1999.

139. Brunet A, Bonni A, Zigmond MJ, Lin MZ, Juo P, Hu LS, Anderson MJ, Arden KC, Blenis J and Greenberg ME: Akt promotes cell survival by phosphorylating and inhibiting a forkhead transcription factor. Cell 96: 857-868, 1999.

140. Medema RH, Kops GJ, Bos JL and Burgering BM: Forkhead transcription factors mediate cell-cycle regulation by Ras and PKB through p27kip1. Nature 404: 782-787, 2000.

141.Dijkers PF, Medema RH, Pals C, Banerji L, Thomas NS, Lam EW, Burgering BM, Raaijmakers JA, Lammers JW, Koenderman L and Coffer PJ: Forkhead transcription factor FKHR-L1 modulates cytokine-dependent transcriptional regulation of p27Kip1. Mol Cell Biol 20: 9138-9148, 2000.

142. Mayo LD and Donner DB: A phopphatidylinositol 3-kinase/ Akt pathway promotes translocation of Mdm2 from the cytoplasm to the nucleus. Proc Natl Acad Sci USA 98: 10983-10985, 2001.

143. Gottlieb TM, Leal JF, Seger R, Taya Y and Oren M: Cross-talk between Akt, p53 and Mdm2: possible implications for the regulation of apoptosis. Oncogene 21: 1299-1303, 2002.

144.Zhou BP and Hung MC: Novel targets of Akt, p21(Cip1.WAF1) and MDM2. Semin Oncol 29: 62-70, 2002.

145. Dan HC, Sun M, Naneko S, Feldman RI, Nicosia SV, Wang HG, Tsang BK and Cheng JQ: Akt phosphorylation and stabilization of X-linked inhibitor of apoptosis protein (XIAP). J Biol Chem 279: 5405-5412, 2004.

146. You H, Pellegrini M, Tsuchihara K, Yamamoto K, Hacker G, Erlacher M, Villunger A and Mak TW: FOXO3 $\alpha$-dependent regulation of Puma in response to cytokine/growth factor withdrawal. J Exp Med 203: 1657-1663, 2006.

147. Obexer P, Geiger K, Ambros PF, Meister B and Ausseriechner MJ: FKHRL 1-mediated expression of Noxa and Bim induces apoptosis via the mitochondria in neuroblastoma cells. Cell Death Differ 14: 534-547, 2007.

148. Ozes ON, Mayo LD, Gustin JA, Pfeffer SR, Pfeffer LLM and Donner DB: NF-kappaB activation by tumor necrosis factor requires the Akt serine-threonine kinase. Nature 401: 82-85, 1999.

149. Romashkova JA and Makarov SS: NF-kappaB is a target of Akt in anti-apoptotic PDGF signaling. Nature 401: 86-90, 1999.

150. Mayo MW and Baldwin AS: The transcription factor NF-kappaB: control of oncogenesis and cancer therapy resistance. Biochem Biophys Acta 1470: M55-M62, 2000.

151. Madrid LV, Wang CY, Guttridge DC, Schottelius AJ, Baldwin AS and Mayo MW: Akt suppresses apoptosis by stimulating the transactivation potential of the Rel A/p65 subunit of NF-kappaB. Mol Cell Biol 20: 1626-1638, 2000.

152. Howe CJ, LaHair MM, Maxwell JA, Lee JT, Robinson PJ, Rodriguez-Mora OM, McCubrey JA and Franklin RA: Participation of the calcium/calmodulin-dependent kinases in hydrogen peroxide-induced Ikappa B phosphorylation in human $T$ lymphocytes. J Biol Chem 277: 30469-30476, 2002.

153. Howe CJ, LaHair MM, McCubrey JA and Franklin RA: Redox regulation of the CaM-kinases. J Biol Chem 279: 44573-44581, 2004. 
154.Hu MC, Lee DF, Xia W, Golfman LS, Ou-Yang F, Yang JY, Zou Y, Bao S, Hanada N, Saso H, Kobayashi R and Hung MC: IkappaB kinase promotes tumorigenesis through inhibition of forkhead FOXO3 $\alpha$. Cell 117: 225-237, 2004.

155. Franklin RA, Rodriguez-Mora OG, LaHair MM and McCubrey JA: Activation of the calcium/calmodulin-dependent protein kinases as a consequence of oxidative stress. Antioxid Redox Signal 8: 1807-1817,2006.

156. Garcia R, Franklin RA and McCubrey JA: Cell death of MCF-7 human breast cancer cells induced by EGFR activation in the absence of other growth factors. Cell Cycle 5: 1840-1846, 2006.

157. LaHair MM, Howe CJ, Rodriguez-Mora OG, McCubrey JA and Franklin RA: Molecular pathways leading to oxidative stressinduced phosphorylation of Akt. Antioxid Redox Signal 8: 1749-1756, 2006.

158. Garcia R, Franklin RA and McCubrey JA: EGF induces cell motility and multi-drug resistance gene expression in breast cancer cells. Cell Cycle 5: 2820-2826, 2006.

159. Rodriguez-Mora OG, LaHair MM, Evans MJ, Kovacs CJ, Allison RR, Sibata CH, White KS, McCubrey JA and Franklin RA: Inhibition of the CaM-Kinases augments cell death in response to oxygen radicals and oxygen radical inducing cancer therapies in MCF-7 human breast cells. Cancer Biol Ther 5: 1022-1030, 2006.

160. Shishodia S and Aggarwal BB: Nuclear factor-kappaB activation mediates cellular transformation, proliferation, invasion angiogenesis and metastasis of cancer. Cancer Treat Res 119: 139-173, 2004.

161.Du K and Montminy M: CREB is a regulatory target for the protein kinase Akt/PKB. J Biol Chem 273: 32377-32379, 1998

162. Arcinas M, Heckman CA, Mehew JW and Boxer LM: Molecular mechanisms of transcriptional control of bcl-2 and c-myc in follicular and transformed lymphoma. Cancer Res 61: 5202-5206, 2001.

163. Mahalingam $\mathrm{M}$ and Templeton DJ: Constitutive activation of S6 kinase by deletion of amino-terminal autoinhibitory and rapamycin sensitivity domains. Mol Cell Biol 16: 405-413, 1996.

164.Dufner A, Anjelkovic M, Burgering BMT, Hemmings B and Thomas G: Protein kinase B localization and activation and eukaryotic translational initiation factor 4E-binding protein phosphorylation. Mol Cell Biol 19: 4525-4534, 1999.

165. Romanelli A, Martin KA, Toker A and Bleinis J: p70 S6 Kinase is regulated by protein kinase $\mathrm{C} \zeta$ and participates in a phosphoinositide 3-kinase-regulated signaling complex. Mol Cell Biol 19: 2921-2928, 1999.

166. Harada H, Andersen JS, Mann M, Terada N and Korsmeyer SJ: P70S6 kinase signals cell survival as well as growth, inactivating the pro-apoptotic molecule Bad. Proc Natl Acad Sci USA 98: 9666-9670, 2001

167.Edinger AL and Thompson CB: An activated mTOR mutant supports growth factor-independent, nutrient-dependent cell survival. Oncogene 23: 5654-5663, 2004.

168. Panwalkar A, Verstovsek S and Giles FJ: Mammalian target of rapamycin inhibition as therapy for hematologic malignancies Cancer 100: 657-666, 2004

169. Jonassen AK, Mjos OD and Sack MN: p70S6 kinase is a functional target of insulin activated Akt cell-survival. Biochem Biophys Res Commun 315: 160-165, 2004.

170.Ma L, Chen Z, Erdjument-Bromage H, Tempst P and Pandolfi PP: Phosphorylation and functional inactivation of TSC2 by Erk implications for tuberous sclerosis and cancer pathogenesis. Cell 121: 179-193, 2005

171. Li J, Yen C, Liaw D, Podsypanina K, Bose S, Wang SI, Puc J, Miliaresis C, Rodgers L, McCombie R, Bigner SH, Giovanella BC, Ittmann M, Tycko B, Hibshoosh H, Wigler MH and Parsons R: PTEN, a putative protein tyrosine phosphatase gene mutated in human brain, breast and prostate cancer. Science 275: 1943-1947, 1997

172. Steck PA, Pershouse MA, Jasser SA, Yung WK, Lin H, Ligon AH, Langford LA, Baumgard ML, Hattier T, Davis T, Frye C, Hu R, Swedlund B, Teng DH and Tavtigian SV: Identification of a candidate tumour suppressor gene, MMAC1, at chromosome $10 \mathrm{q} 23.3$ that is mutated in multiple advanced cancers. Nat Genet 15: 356-362, 1997.

173. Li DM and Sun H: TEP1, encoded by a candidate tumor suppressor locus, is a novel protein tyrosine phosphatase regulated by transforming growth factor beta. Cancer Res 57: 2124-2129, 1997.

174. Steelman LS, Bertrand FE and McCubrey JA: The complexity of PTEN: mutation, marker and potential target for therapeutic intervention. Expert Opin Ther Targets 8: 537-550, 2004.
175. Shaw RJ and Cantley LC: Ras, PI(3)K and mTOR signaling controls tumour cell growth. Nature 441: 424-430, 2006.

176. Mahimainathan L and Choudhury GG: Inactivation of plateletderived growth factor receptor by the tumor suppressor PTEN provides a novel mechanism of action of the phosphatase. J Biol Chem 279: 15258-15268, 2004.

177. Raftopoulou M, Etienne-Manneville S, Self A, Nicholls S and Hall A: Regulation of cell migration by the $\mathrm{C} 2$ domain of the tumor suppressor PTEN. Science 303: 1179-1181, 2004.

178. Damen JE, Liu L, Rosten P, Humphries RK, Jefferson AB, Majerus PW and Krystal G: The $145-\mathrm{kDa}$ protein induced to associate with Shc by multiple cytokines is an inositol tetraphosphate and phosphatidylinositol 3,4,5-triposphate 5-phosphatase. Proc Natl Acad Sci USA 93: 1689-1693, 1996.

179. Kavanaugh WM, Pot DA, Chin SM, Deuter-Reinhard M, Jefferson AB, Norris FA, Masiarz FR, Cousens LS, Majerus PW and Williams LT: Multiple forms of an inositol polyphosphate 5-phosphaatase from signaling complexes with Shc and Grb2. Curr Biol 6: 438-445, 1996.

180.Lioubin MN, Algate PA, Tsai S, Carlberg K, Aebersold A and Rohrschneider LR: P150Ship, a signal transduction molecule with inositol polyphosphate-5-phosphatase activity. Genes Devel 10: 1084-1095, 1996

181. Muraille E, Pesesse X, Kuntz C and Erneux C: Distribution of the src-homology-2-domain-containing inositol 5-phosphatase SHIP-2 in both non-haemopoietic and haemopoietic cells and possible involvement in SHIP-2 in negative signaling of B-cells. Biochem J 342: 697-705, 1999.

182. Taylor V, Wong M, Brandts C, Reilly L, Dean NM, Cowsert LM, Moodie S and Stokoe D: 5'Phospholipid phosphatase SHIP-2 causes protein kinase B inactivation and cell cycle arrest in glioblastoma cells. Mol Cell Biol 20: 6860-6871, 2000.

183. Rommel C, Clarke BA, Zimmermann S, Nuñez L, Rossman R, Reid K, Moelling K, Yancopoulos GD and Glass DJ: Differentiation stage-specific inhibition of the Raf-MEK-ERK pathway by Akt. Science 286: 1738-1741, 1999.

184.Zimmermann S and Moelling K: Phosphorylation and regulation of Raf by Akt (protein kinase B). Science 286: 1741-1744, 1999.

185. Guan K, Figueroa C, Brtva TR, Zhu T, Taylor J, Barber TD and Vojtek AB: Negative regulation of the serine/threonine kinase B-Raf by Akt. J Biol Chem 275: 27354-27359, 2000.

186.Zhang BH, Tang E, Zhu T, Greenberg M, Vojtek A and Guan KL: Serum and glucocorticoid-inducible kinase SGK phosphorylates and negatively regulates B-Raf. J Biol Chem 276: 31620-31626, 2001

187. Majewski M, Nieborowska-Skorska M, Salomoni P, Slupianek A, Reiss K, Trotta R, Calabretta B and Skorski T: Activation of mitochondrial Raf-1 is involved in the antiapoptotic effects of Akt. Cancer Res 59: 2815-2819, 1999.

188. McCubrey JA, Steelman LS, Blalock WL, Lee JT, Moye PW, Chang F, Pearce M, Shelton JG, White MK, Franklin RA and Pohnert SC: Synergistic effects of PI3K/Akt on abrogation of cytokine-dependency induced by oncogenic Raf. Adv Enzyme Regul 41: 289-323, 2001.

189.Gelfanov VM, Burgess GS, Litz-Jackson S, King AJ, Marshall MS, Nakshatri H and Boswell HS: Transformation of interleukin-3-dependent cells without participation of Stat5/ Bcl-xL:cooperation of akt with raf/erk leads to p65 nuclear factor $\mathrm{\kappa B}$-mediated anti-apoptosis involving c-IAP2. Blood 15: 2508-2517, 2001

190. Von Gise A, Lorenz P, Wellbrock C, Hemmings B, BerberichSiebelt F, Rapp UR and Troppmair J: Apoptosis suppression by Raf-1 and MEK1 requires MEK and phosphatidylinositol 3-kinase dependent signals. Mol Cell Biol 21: 2324-2336, 2001.

191. Shelton JG, Steelman LS, Lee JT, Knapp SL, Blalock WL, Moye PW, Franklin RA, Pohnert SC, Mirza AM, McMahon M and McCubrey JA: Effects of the RAF/MEK/ERK and PI3K/ AKT signal transduction pathways on the abrogation of cytokinedependence and prevention of apoptosis in hematopoietic cells. Oncogene 22: 2478-2492, 2003

192. Shelton JG, Blalock WL, White ER, Steelman LS and McCubrey JA: Ability of the activated PI3K/Akt oncoproteins to synergize with MEK1 and induce cell cycle progression and abrogate the cytokine-dependence of hematopoietic cells. Cell Cycle 3: 503-512, 2004.

193.Zhao S, Konopleva M, Cabreira-Hansen M, Xie Z, Hu W, Milella M, Estrov Z, Mills GB and Andreeff M: Inhibition of phosphatidylinositol 3-kinase dephosphorylates BAD and promotes apoptosis in myeloid leukemias. Leukemia 18: 267-275, 2004. 
194.Rodriguez-Viciana P, Tetsu O, Tidyman WE, Estep AL, Conger BA, Cruz MS, McCormick F and Rauen KA: Germline mutations in genes within the MAPK pathway cause cardiofacio-cutaneous syndrome. Science 311: 1287-1290, 2006.

195. Gire V, Marshall C and Wynford-Thomas D: PI-3-kinase is an essential anti-apoptotic effector in the proliferative response of primary human epithelial cells to mutant RAS. Oncogene 19: 2269-2276, 2000 .

196. Sun H, King AJ, Diaz HB and Marshall MS: Regulation of the protein kinase Raf-1 by oncogenic Ras through phosphatidylinositol 3-kinase, Cdc42/Rac and Pak. Curr Biol 10: 281-284, 2000

197. Hu L, Shi Y, Hsu JH, Gera J, van Ness B and Lichtenstein A: Downstream effectors of oncogenic ras in multiple myeloma cells. Blood 101: 3126-3135, 2003

198. Kubota Y, Ohnishi H, Kitanaka A, Ishida T and Tanaka T: Constitutive activation of PI3K is involved in the spontaneous proliferation of primary acute myeloid leukemia cells: direct evidence of PI3K activation. Leukemia 18: 1438-1440, 2004.

199. Cuni S, Perez-Aciego P, Perez-Chacon G, Vargas JA, Sánchez A Martín-Saavedra FM, Ballester S, García-Marco J, Jordá J and Durántez A: A sustained activation of PI3K/NF-kappaB pathway is critical for the survival of chronic lymphocytic leukemia B cells. Leukemia 18: 1391-1400, 2004

200 Ninomiya Y, Kato K, Takahashi A, Ueoka Y, Kamikihara T, Arima T, Matsuda T, Kato H, Nishida J and Wake N: K-Ras and $\mathrm{H}$-Ras activation promote distinct consequences on endometrial cell survival. Cancer Res 64: 2759-2765, 2004.

201. Jucker M, Sudel K, Horn S, Sickel M, Wegner W, Fiedler W and Feldman RA: Expression of a mutated form of the p85alpha regulatory subunit of phosphatidylinositol 3-kinase in a Hodgkin's lymphoma-derived cell line (CO). Leukemia 16: 894-901, 2002.

202. Bader AG, Kang S, Zhao L and Vogt PK: Oncogenic PI3K deregulates transcription and translation. Nat Rev Cancer 5: 921-929, 2005

203. Engleman JA, Luo J and Canley LC: The evolution phosphatidylinositol 3-kinases as regulators of growth and metabolism. Nat Rev Genet 7: 606-619, 2006.

204. Vogt PK, Bader AG and Kang S: Phosphoinositide 3-kinase: from viral oncoprotein to drug target. Virology 344: 131-138, 2006.

205. Kang S, Bader AG, Zhao L and Vogt PK: Mutated PI 3-kinases: cancer targets on a silver platter. Cell Cycle 4: 578-581, 2005.

206. Müller CI, Miller CW, Hofmann WK, Gross ME, Walsh CS, Kawamata N, Luong QT and Koeffler HP: Rare mutations of the PIK3CA gene in malignancies of the hematopoietic system as well as endometrium, ovary, prostate and osteosarcomas, and discovery of a PIK3CA pseudogene. Leuk Res 31: 27-32, 2007.

207. Nakahara Y, Nagai H, Kinoshita T, Uchida T, Hatano S, Murate T and Saito H: Mutational analysis of the PTEN/ MMAC1 gene in non-Hodgkin's lymphoma. Leukemia 12: 1277-1280, 1998.

208. Sakai A, Thieblemont C, Wellmann A, Jaffe ES and Raffeld M: PTEN gene alterations in lymphoid neoplasms. Blood 92: 3410-3415, 1998.

209. Dahia PL, Aquiar RC, Alberta J, Kum JB, Caron S, Sill H, Marsh DJ, Ritz J, Freedman A, Stiles C and Eng C: PTEN is inversely correlated with the cell survival factor Akt/PKB and is inactivated via multiple mechanism in haematological malignancies. Human Mol Gen 8: 185-193, 1999.

210. Butler MP, Wang SI, Chaganti RS, Parsons R and DallaFavera R: Analysis of PTEN mutations and deletions in B-cell non-Hodgkin's lymphomas. Genes Chromosomes Cancer 24: 322-327, 1999

211.Aggerholm A, Gronbaek K, Guldberg P and Hokland P: Mutational analysis of the tumour suppressor gene MMAC1/ PTEN in malignant myeloid disorders. Eur J Haematol 65: 109-113, 2000.

212.Leslie NR, Gray A, Pass I, Orchiston EA and Downes CP: Analysis of the cellular functions of PTEN using catalytic domain and C-terminal mutations: differential effects of Cterminal deletion on signaling pathways downstream of phosphoinositide 3-kinase. Biochem J 346: 827-833, 2000.

213. Herranz M, Urioste M, Santos J, Martinez-Delgado JB, Rivas C, Benitez J and Fernández-Piqueras J: Allelic losses and genetic instabilities of PTEN and p73 in non-Hodgkin lymphomas. Leukemia 14: 1325-1327, 2000.

214. Staal SP: Molecular cloning of the Akt oncogene and its human homologues AKT1 and AKT2: amplification of AKT1 in a primary human gastric adenocarcinoma. Proc Natl Acad Sci USA 84: 5034-5037, 1987.
215. Cheng JQ, Godwin AK, Bellacosa A, Taguchi T, Franke TF, Hamilton TC, Tsichlis PN and Testa JR: AKT2, a putative oncogene encoding a member of a subfamily of protein-serine/ threonine kinases, is amplified in human ovarian carcinomas. Proc Natl Acad Sci USA 89: 9267-9271, 1992.

216. Cheng JQ, Ruggeri B, Klein WM, Sonoda G, Altomare DA, Watson DK and Testa JR: Amplification of AKT2 in human pancreatic cells and inhibiton of AKT2 expression and tumorigenicity by anti-sense RNA. Proc Natl Acad Sci USA 93: 3636-3641, 1996.

217. Graff JR, Konicek BW, McNulty AM, Wang Z, Houck K, Allen S, Paul JD, Hbaiu A, Goode RG, Sandusky GE, Vessella RL and Neubauer BL: Increased Akt activity contributes to prostate cancer progression by dramatically accelerating prostate tumor growth and diminishing $\mathrm{p} 27 \mathrm{Kip}-1$ expression. J Biol Chem 275: 24500-24505, 2000.

218. Luo JM, Yoshida H, Komura S, Ohishi N, Pan L, Shigeno K, Hanamura I, Miura K, Iida S, Ueda R, Naoe T, Akao Y, Ohno R and Ohnishi K: Possible dominant-negative mutation of the SHIP gene in acute myeloid leukemia. Leukemia 17: 1-8, 2003.

219.Luo JM, Liu ZL, Hao HL, Wang FX, Dong ZR and Ohno R: Mutation analysis of SHIP gene in acute leukemia. Zhongguo Shi Yan Xue Ye Xue Za Zhi 12: 420-426, 2004.

220.Lin J, Adam RM, Santiestevan E and Freeman MR: The phosphatidylinositol 3'-kinase pathway is a dominant growth factor-activated cell survival pathway in $\mathrm{LNCaP}$ human prostate carcinoma cells. Cancer Res 59: 2891-2897, 1999.

221. Hietakangas V and Cohen SM: Re-evaluating Akt regulation: role of TOR complex 2 in tissue growth. Genes Dev 21: 632-637, 2007.

222. Fry MJ: Phosphoinositide 3-kinase signalling in breast cancer: how big a role might it play? Breast Cancer Res 3: 304-312, 2001.

223. Lin X, Bohle AS, Dohrmann P, Leuschner I, Schulz A, Kremer B and Fändrich F: Overexpression of phosphatidylinositol 3-kinase in human lung cancer. Langenbecks Arch Surg 386: 293-301, 2001.

224. Krasilnikov M, Adler V, Fuchs SY, Dong Z, HaimovitzFriedman A, Herlyn M and Ronai Z: Contribution of phosphatidylinositol 3-kinase to radiation resistance in human melanoma cells. Mol Carcinog 24: 64-69, 1999.

225. Martinez-Lorenzo MJ, Anel A, Monleon I, Sierra JJ, Piñeiro A, Naval J and Alava MA: Tyrosine phosphorylation of the $\mathrm{p} 85$ subunit of phosphatidylinositol 3-kinase correlates with high proliferation rates in sublines derived from the Jurkat leukemia. Int J Biochem Cell Biol 32: 435-445, 2000.

226. Shou J, Massarweh S, Osborne CK, Wakeling AE, Ali S, Weiss $\mathrm{H}$ and Schiff R: Mechanisms of tamoxifen resistance: increased estrogen receptor-HER2/neu cross-talk in ER/HER2positive breast cancer. J Natl Cancer Inst 96: 926-935, 2004.

227. Frogne T, Jepsen JS, Larsen SS, Fog CK, Brockdorff BL and Lykkesfeldt AE: Antiestrogen-resistant human breast cancer cells require activated protein kinase B/Akt for growth. Endocr Relat Cancer 12: 599-614, 2005.

228. Kirkegaard T, Witton CJ, McGlynn LM, Tovey SM, Dunne B, Lyon A and Bartlett JM: AKT activation predicts outcome in breast cancer patients treated with tamoxifen. J Pathol 207: 139-146, 2005.

229. Kornblau SM, Womble M, Qiu YH, Jackson CE, Chen W, Konopleva M, Estey EH and Andreeff M: Simultaneous activation of multiple signal transduction pathways confers poor prognosis in acute myelogenous leukemia. Blood 108: 2358-2365, 2006

230. Nyakern M, Tazzari PL, Finelli C, Bosi C, Follo MY, Grafone T, Piccaluga PP, Martinelli G, Cocco L and Martelli AM: Frequent elevation of Akt kinase phosphorylation in blood marrow and peripheral blood mononuclear cells from high-risk myelodysplastic syndrome patients. Leukemia 20: 230-238, 2006.

231. Mantovani I, Cappellini A, Tazzari PL, Papa V, Cocco L and Martelli AM: Caspase-dependent cleavage of 170-kDa Pglycoprotein during apoptosis of human T-lymphoblastoid CEM cells. J Cell Physiol 207: 836-844, 2006.

232. Nyakern M, Cappellini A, Mantovani J and Martelli AM: Synergistic induction of apoptosis in yhuman leukemia T cells by the Akt inhibitor perifosine and etoposide through activation of intrinsic and Fas-mediated extrinsic cell death pathways. Mol Cancer Ther 5: 1559-1570, 2006.

233. Martelli AM, Nyakern M, Tabellini G, Bortul R, Tazzari PL, Evangelisti C and Cocco L: Phosphoinositide 3-kinase/Akt signaling pathway and its therapeutical implications for human acute myelid leukemia. Leukemia 20: 911-928, 2006. 
234. Navolanic PM, Steelman LS and McCubrey JA: EGFR family signaling and its association with breast cancer development and resistance to chemotherapy. Int J Oncol 22: 237-252, 2003.

235. Rhei E, Kang L, Bogomolniy F, Federici MG, Borgen PI and Boyd J: Mutation analysis of the putative tumor suppressor gene PTEN/MMAC1 in primary breast carcinomas. Cancer Res 57: 3657-3659, 1997.

236. Singh B, Ittmann MM and Krolewski JJ: Sporadic breast cancers exhibit loss of heterozygosity on chromosome segment 10q23 close to the Cowden disease locus. Genes Chromosome Cancer 21: 166-171, 1998.

237. Feilotter HE, Coulon V, McVeigh JL, Boag AH, DorionBonnet F, Duboue B, Latham WC, Eng C, Mulligan LM and Longy M: Analysis of the 10q23 chromosomal region and the PTEN gene in human sporadic breast carcinoma. Br J Cancer 79: 718-723, 1999

238. DeGraffenried LA, Fulcher L, Friedrichs WE, Grunwald V, Ray RB, Hidalgo M and Hidalgo M: Reduced PTEN expression in breast cancer cells confers susceptibility to inhibitors of the PI3 kinase/Akt pathway. Ann Oncology 15: 1510-1516, 2004.

239. Hollestelle A, Elstrodt F, Nagel JHA and Kallemeijn WW: Phosphatidylinositol-3-OH kinase or Ras pathway mutations in human breast cancer cell lines. Mol Cancer Res 5: 195-201, 2007.

240. Garcia JM, Silva J, Pena C, Garcia V, Rodriguez R, Cruz MA, Cantos B, Provencio M, Espana P and Bonilla R: Promoter methylation of the PTEN gene is a common molecular change in breast cancer. Genes Chromosomes Cancer 41: 117-124, 2004.

241.Tsutsui S, Inoue H, Yasuda K, Suzuki K, Higashi H, Era S and Mori M: Reduced expression of PTEN protein and its prognostic implications in invasive ductal carcinoma of the breast. Oncology 68: 398-404, 2005.

242. Trotman LC, Wang X, Alimonti A, Chen Z, Teruya-Feldstein J, Yang H, Pavletich NP, Carver BS, Cordon-Cardo C, Erdjument-Bromage H, Tempst P, Chi SG, Kim HJ, Misteli T, Jiang X and Pandolfi PP: Ubiquitination regulates PTEN nuclear import and tumor suppression. Cell 128: 141-156, 2007.

243. Shen WH, Balajee AS, Wang J, Wu H, Eng C, Pandolfi PP and Yin Y: Essential role for nuclear PTEN in maintaining chromosomal integrity. Cell 128: 157-170, 2007.

244. Tokunaga E, Kimura Y, Mashino K, Oki E, Kataoka A, Ohno S, Morita M, Kakeji Y, Baba H and Maehara Y: Activation of $\mathrm{PI} 3 \mathrm{~K} / \mathrm{Akt}$ signaling and hormone resistance in breast cancer. Breast Cancer 13: 137-144, 2006.

245. Greenman C, Stephens P, Smith R, Dalgliesh GL, Hunter C, Bignell G, Davies H, Teague J, Butler A, Stevens C, Edkins S, O'Meara S, Vastrik I, Schmidt EE, Avis T, Barthorpe S, Bhamra G, Buck G, Choudhury B, Clements J, Cole J, Dicks E, Forbes S, Gray K, Halliday K, Harrison R, Hills K, Hinton J, Jenkinson A, Jones D, Menzies A, Mironenko T, Perry J, Raine K, Richardson D, Shepherd R, Small A, Tofts C, Varian J, Webb T, West S, Widaa S, Yates A, Cahill DP, Louis DN, Goldstraw P, Nicholson AG, Brasseur F, Looijenga L, Weber BL, Chiew YE, DeFazio A, Greaves MF, Green AR, Campbell P, Birney E, Easton DF, Chenevix-Trench G, Tan MH, Khoo SK, Teh BT, Yuen ST, Leung SY, Wooster R, Futreal PA and Stratton MR: Patterns of somatic mutation in human cancer genomes. Nature 446: 153-158, 2007.

246. Shelton JG, Steelman LS, Abrams SL, Bertrand FE, Franklin RA, McMahon M and McCubrey JA: The epidermal growth factor receptor as a target for therapeutic intervention in numerous cancers: what's genetics got to do with it? Expert Opin Ther Targets 9: 1009-1030, 2005.

247. Deng X, Xiao L, Lang W, Gao F, Ruvolo P and May WS Jr: Novel role for JNK as a stress-activated Bcl2 kinase. J Biol Chem 276: 23681-23688, 2001

248. Martelli AM, Tazzari PL, Evangelisti C, Chiarini F, Blalock WL, Billi AM, Manzoli L, McCubrey JA and Cocco L: Targeting the phosphatidylinositol 3-kinase/Akt/mammalian target of rapamycin module for acute myelogenous leukemia therapy: from bench to bedside. Curr Med Chem 14: 2009-2023, 2007.

249. Devarajan E, Sahin AA, Chen JS, Krishnamurthy RR, Aggarwal N, Brun AM, Sapino A, Zhang F, Sharma D, Yang XH, Tora AD and Mehta K: Down-regulation of caspase 3 in breast cancer: a possible mechanism for chemoresistance. Oncogene 21: 8843-8851, 2002.

250.Liang Y, Yan C and Schor NF: Apoptosis in the absence of caspase 3. Oncogene 20: 6570-6578, 2001.
251. Twiddy D, Gohen GM, MacFarlane M and Cain K: Casape-7 is directly activated by the $\sim 700-\mathrm{kDa}$ apoptosome complex and is released as a stable XIAP-caspase-7 200-kDa complex. J Biol Chem 281: 3876-3888, 2006.

252. Gardai SJ, Whitlock BB, Xiao YQ, Bratton DB and Henson PM: Oxidants inhibit ERK/MAPK and prevent its ability to delay neutrophil apoptosis downstream of mitochondrial changes and at the level of XIAP. J Biol Chem 279: 44695-44703, 2004.

253. Lee JT Jr and McCubrey JA: Targeting the Raf kinase cascade in cancer therapy-novel molecular targets and therapeutic strategies. Expert Opin Ther Targets 6: 659-678, 2002.

254. Hochhaus A, McCubrey JA and Killmann NMB: Spotlight imatinib: a model for signal transduction inhibitors. Leukemia 16: 1205-1206, 2002.

255. Barnes G, Bulusu VR, Hardwick RH, Carroll N, Hatcher H, Earl HM, Save VE, Balan K and Jamieson NV: A review of the surgical management of metastatic gastrointestinal stromal tumours (GISTs) on imatinib mesylate (Glivec trade mark). Int J Surg 3: 206-212, 2005.

256. Lynch TJ, Bell DW, Sordella R, Gurubhagavatula S, Okimoto RA, Bannigan BW, Harris PL, Haserlat SM, Supko JB, Haluska FG, Louis DN, Christiani DC, Settleman J and Haber DA: Activating mutations in the epidermal growth factor receptor underlying responsiveness of non-small cancer to gefitinib. N Engl J Med 350: 2129-2139, 2004.

257. Sordella R, Bell DW, Haber DA and Settleman J: Gefitinibsensitizing EGFR mutations in lung cancer activate anti-apoptotic pathways. Science 305: 1163-1167, 2004.

258. Pao W, Miller V, Zakowski M, Doherty J, Politi K, Sarkaria I, Singh B, Heelan R, Rusch V, Fulton L, Mardis E, Kupfer D, Wilson R, Kris M and Varmus H: EGF receptor mutations are common in lung cancers from 'never smokers' are associated with sensitivity of tumors to gefitinib and erlotinib. Proc Natl Acad Sci USA 101: 13306-13311, 2004

259. Pao W, Wang TY, Riely GJ, Miller VA, Pan Q, Ladanyi M, Zakowski MF, Heelan RT, Kris MG and Varmus HE: KRAS mutations and primary resistance of lung adenocarcinomas to gefitinib or erlotinib. PLoS Med 2: 57-61, 2005.

260. Sequist LV, Haber DA and Lynch TJ: Epidermal growth factor receptor mutations in non-small cell lung cancer; predicting clinical response to kinase inhibitors. Clin Cancer Res 11: 5668-5670, 2005.

261. Tortora G, Bianco R, Daniele G, Ciardiello F, McCubrey JA, Ricciardi MR, Ciuffreda L, Cognetti F, Tafuri A and Milella M: Overcoming resistance to molecularly targeted anticancer therapies: rational drug combinations based on EGFR and MAPK inhibition for solid tumors and hematological malignancies. Drug Resist Updat 10: 81-100, 2007

262. Sun SY, Rosenberg LM, Wang X, Zhou Z, Yue P, Fu H and Khuri FR: Activation of Akt and eIF4E survival pathways by rapamycin-mediated mammalian target of rapamycin inhibition. Cancer Res 65: 7052-7058, 2005.

263. Konopleva M, Contractor R, Tsao T, Samudio I, Ruvolo PP, Kitada S, Deng X, Zhai D, Shi YX, Sneed T, Verhaegen M, Soengas M, Ruvolo VR, McQueen T, Schober WD, Watt JC, Jiffar T, Ling X, Marini FC, Harris D, Dietrich M, Estrov Z, McCubrey J, May WS, Reed JC and Andreeff M: Mechanisms of apoptosis sensitivity and resistance to the $\mathrm{BH} 3$ mimetic ABT-737 in acute myeloid leukemia. Cancer Cell 10: 375-388, 2006.

264. Kojima K, Konopleva M, McQueen T, O'Brien S, Plunkett W and Andreeff M: MDM2 inhibitor Nutlin 3a induces p53mediated apoptosis by transcription-dependent and transcriptionindependent mechanisms and may overcome Atm-mediated resistance to fludarabine in chronic lymphocytic leukemia. Blood 108: 993-1000, 2006.

265. Heimbrook DC, Huber HE, Stirdivant SM, Claremon D, Liverton N, Patrick DR, Selnick H, Ahern J, Conroy R, Drakas R, Falconi N and Hancock P: Identification of potent, selective kinase inhibitors of Raf. Proc Am Assoc Cancer Res Annual Meeting 39: 558, 1998.

266. Hall-Jackson CA, Eyers PA, Cohen P, Goedert M, Boyle FT, Hewitt N, Plant $\mathrm{H}$ and Hedge P: Paradoxical activation of Raf by a novel Raf inhibitor. Chem Biol 6: 559-568, 1999.

267.Lyons JF, Wilhelm S, Hibner B and Bollag G: Discovery of a novel Raf kinase inhibitor. Endocr Relat Cancer 8: 219-225, 2001.

268. Blagosklonny MV: Hsp-90-associated oncoproteins: multiple targets of geldanamycin and its analogs. Leukemia 16: 455-462, 2002 . 
269. Shelton JG, Moye PW, Steelman LS, Blalock WL, Lee JT, Franklin RA, McMahon M and McCubrey JA: Differential effects of kinase cascade inhibitors on neoplastic and cytokine-mediated cell proliferation. Leukemia 17: 1765-1782, 2003.

270. Lee JT, Steelman LS and McCubrey JA: PI3K Activation leads to MRP1 expression and subsequent chemoresistance in advanced prostate cancer cells. Cancer Res 64: 8397-8404, 2004.

271. Workman P: Altered states: selectively drugging the Hsp90 cancer chaperone. Trends Mol Med 10: 47-51, 2004.

272. Shimamura T, Lowell AM, Engelman JA and Shapiro GI: Epidermal growth factor receptors harboring kinase domain mutations associate with the heat shock protein 90 chaperone and are destabilized following exposure to geldanamycins. Cancer Res 65: 6401-6408, 2005.

273. Sain N, Krishnan B, Ormerod MG, De Rienzo A, Liu WM, Kaye SB, Workman P and Jackman AL: Potentiation of paclitaxel activity by the HSP90 inhibitor 17-allylamino-17-demethoxygeldanamycin in human ovarian carcinoma cell lines with high levels of activated AKT. Mol Cancer Ther 5: 1197-1208, 2006.

274. Rodriguez-Viciana P, Warne PH, Dhand R, Vanhaesebroeck B, Gout I, Fry MJ, Waterfield MD and Downward J: Phosphatidylinositol-3-OH kinase as a direct target of Ras. Nature 370: 527-532, 1994

275. Delaney AM, Printon JA, Chen H, Faumann EB and Dudley DT: Identification of a novel mitogen-activated protein kinase kinase activation domain recognized by the inhibitor PD 184352. Mol Cell Biol 22: 7593-7602, 2002.

276. Davies SP, Reddy H, Caivano M and Cohen P: Specificity and mechanism of action of some commonly used protein kinase inhibitors. Biochem J 351: 95-105, 2000

277. Ohren JF, Chen H, Pavlovsky A, Whitehead C, Zhang E, Kuffa P, Yan C, McConnell P, Spessard C, Banotai C, Mueller WT, Delaney A, Omer C, Sebolt-Leopold J, Dudley DT, Leung IK, Flamme C, Warmus J, Kaufman M, Barrett S, Tecle $\mathrm{H}$ and Hasemann CA: Structures of human MAP kinase kinase 1 (MEK1) and MEK2 describe novel non-com-petitive kinase inhibition. Nat Struct Mol Biol 11: 1192-1197, 2004.

278.Tai YT, Fulciniti M, Hideshima T, Song W, Leiba M, Li XF, Rumizen M, Burger P, Morrison A, Podar K, Chauhan D, Tassone P, Richardson P, Munshi NC, Ghobrial I and Anderson KC: Targeting MEK induces myeloma-cell cytotoxicity and inhibits osteoclastogenesis. Blood 110: $1656-1663,2006$

279. Wang D, Boerner SA, Winkler JD and LoRusso PM: Clinical experience of MEK inhibitors in cancer therapy. Biochim Biophys Acta 1773: 1248-1255, 2007

280. Yeh TC, Marsh V, Bernat BA, Ballard J, Colwell H, Evans RJ, Parry J, Smith D, Brandhuber BJ, Gross S, Marlow A, Hurley B, Lyssikatos J, Lee PA, Winkler JD, Koch K and Wallace E: Biological characterization of ARRY-142886 (AZD6244), a potent, highly selective mitogen-activated protein kinase kinase 1/2 inhibitor. Clin Cancer Res 13: 1576-1583, 2007.

281. Mazzucchelli C, Vantaggiato C, Ciamei A, Fasano S, Pakhotin P, Krezel W, Welzl H, Wolfer DP, Pages G, Valverde O, Marowsky A, Porrazzo A, Orban PC, Maldonado R, Ehrengruber MU, Cestari V, Lipp HP, Chapman PF, Pouysségur J and Brambilla R: Knockout of ERK1 MAP kinase enhances synaptic plasticity in the striatum and facilitates striatalmediated learning and memory. Neuron 34: 807-820, 2002.

282. Rolfe M, McLeod LE, Pratt PF and Proud CG: Activation of protein synthesis in cardiomyocytes by the hypertrophic agent phenylephrine requires the activation of ERK and involves phosphorylation of tuberous sclerosis complex 2 (TSC2). Biochem J 388: 973-984, 2005

283. Sosman JA, Puzanov I and Atkins MB: Opportunities and obstacles to combination targeted therapy in renal cell cancer. Clin Cancer Res 13: 764s-769s, 2007.

284. Costa LJ, Gemmill RM and Drabkin HA: Upstream signaling inhibition enhances rapamycin effect on growth of kidney cancer cells. Urology 69: 596-602, 2007

285. Janmaat ML, Rodriguez JA, Gallegos-Ruiz M, Kruyt FA and Giaccone G: Enhanced cytotoxicity induced by gefitinib and specific inhibitors of the Ras or phosphatidyl inositol-3 kinase pathways in non-small cell lung cancer cells. Int J Cancer 118: 209-214, 2006

286. Wang LH, Chan JLK and Li W: Rapamycin together with herceptin significantly increased anti-tumor efficacy compared to either alone in ErbB2 over expressing breast cancer cells. Int J Cancer 121: 2911-2918, 2007.
287. Konecny GE, Pegram MD, Venkatesan N, Finn R, Yang G, Rahmeh M, Untch M, Rusnak DW, Spehar G, Mullin RJ, Keith BR, Gilmer TM, Berger M, Podratz KC and Slamon DJ: Activity of the dual kinase inhibitor lapatinib (GW572016) against HER-2-overexpressing and trastuzumab-treated breast cancer cells. Cancer Res 66: 1630-1639, 2006.

288. Yu C, Mao X and Li WX: Inhibition of the PI3K pathway sensitizes fludarabine-induced apoptosis in human leukemic cells through an inactivation of MAPK-dependent pathway. Biochem Biophys Res Commun 331: 391-397, 2005.

289. Mondesire WH, Jian W, Zhang H, Ensor J, Hung MC, Mills GB and Meric-Bernstam F: Targeting mammalian target of rapamycin synergistically enhances chemotherapy-induced cyto-toxicity in breast cancer cells. Clin Cancer Res 10: 7031-7042, 2004.

290. Faried LS, Kanuma T, Nakazato T, Tamura T, Kuwano H and Minegishi T: Inhibition of the mammalian target of Rapamycin (mTOR) by Rapamycin increases chemosensi-tivity of CaSki cells to paclitaxel. Eur J Can 42: 934-947, 2006.

291. Dong J, Peng J, Zhang H, Mondesire WH, Jian W, Mills GB, Hung MC and Meric-Bernstam F: Role of glycogen synthase kinase 3 beta in rapamycin-mediated cell cycle regulation and chemosensitivity. Cancer Res 65: 1961-1972, 2005.

292.Hahn M, Li W, Yu C, Rahmani M, Dent P and Grant S: Rapamycin and UCN-01 synergistically induce apoptosis in human leukemia cells through a process that is regulated by the Raf-1/MEK/ERK, Akt, and JNK signal transduction pathways. Mol Cancer Ther 4: 457-470, 2005.

293. Dai Y, Rahmani M, Pei XY, Khanna P, Han SI, Mitchell C, Dent P and Grant S: Farnesyltransferase inhibitors interact synergistically with the Chk1 inhibitor $\mathrm{UCN}-01$ to induce apoptosis in human leukemia cells through interruption of both Akt and MEK/ERK pathways and activation of SEK1/JNK. Blood 105: 1706-1716, 2005

294. Yu K, Lucas J, Zhu T, Zask A, Gaydos C, Toral-Barza L, Gu J, Li F, Chaudhary I, Cai P, Lotvin J, Petersen R, Ruppen M Fawzi M, Ayral-Kaloustian S, Skotnicki J, Mansour T, Frost P and Gibbons J: PWT-458, a novel pegylated-17-hydroxywortmannin, inhibits phosphatidylinositol 3-kinase signaling and suppresses growth of solid tumors. Cancer Biol Ther 4: 538-545, 2005.

295. Abdul-Ghani R, Serra V, Gyorffy B, Jürchott K, Solfmm A, Dietel M and Schäfer R: The PI3K inhibitor LY294002 blocks drug export from resistant colon carcinoma cells overexpressing MRP-1. Oncogene 25: 1743-1752, 2006.

296. Hideshima T, Catley L, Yasui H, Ishitsuka K, Raje N Mitsiades C, Podar K, Munshi NC, Chauhan D, Richardson PG and Anderson KC: Perifosine, an oral bioactive novel alkylphospholipid, inhibits Akt and induces in vitro and in vivo cytotoxicity in human multiple myeloma cells. Blood 107: 4053-4062, 2006.

297. Tazzari PL, Tabellini G, Bortul R, Papa V, Evangelisti C, Grafone T, Martinelli G, McCubrey JA and Martelli AM: The insulin-like growth factor-I receptor kinase inhibitor NVPAEW541 induces apoptosis in acute myeloid leukemia cells exhibiting autocrine insulin-like growth factor-I secretion. Leukemia 21: 886-896, 2007

298. Luo Y, Shoemaker AR, Liu X, Woods KW, Thomas SA, De Jong R, Han EK, Li T, Stoll VS, Powlas JA, Oleksijew A, Mitten MJ, Shi Y, Guan R, McGonigal TP, Klinghofer V, Johnson EF, Leverson JD, Bouska JJ, Mamo M, Smith RA, Gramling-Evans EE, Zinker BA, Mika AK, Nguyen PT, Oltersdorf T, Rosenberg SH, Li Q and Giranda VL: Potent and selective inhibitors of Akt kinases slow the progress of tumors in vivo. Mol Cancer Ther 4: 977-986, 2005.

299.Zhong X, Li X, Wang G, Zhu Y, Hu G, Zhao J, Neace C, Ding H, Reed E and Li QQ: Mechanisms underlying the synergistic effect of SU5416 and cisplatin on cytotoxicity in human ovarian tumor cells. Int J Oncol 25: 445-451, 2004

300. Sosman JA and Puzanov I: Molecular targets in melanoma from angiogenesis to apoptosis. Clin Cancer Res 12: 2376s-2383s, 2006.

301.Zhu K, Gerbino E, Beaupre DM, Mackley PA, Muro-Cacho C, Beam C, Hamilton AD, Lichtenheld MG, Kerr WG, Dalton W, Alsina M and Sebti SM: Farnesyltransferase inhibitor R115777 (Zarnestra, Tipifarnib) synergizes with paclitaxel to induce apoptosis and mitotic arrest and to inhibit tumor growth of multiple myeloma cells. Blood 105: 4759-4766, 2005.

302. MacKeigan JP, Clements CM, Lich JD, Pope RM, Hod Y and Ting JP: Proteomic profiling drug-induced apoptosis in nonsmall cell lung carcinoma: identification of RS/DJ-1 and RhoGDIalpha. Cancer Res 63: 6928-6934, 2003. 
303. McDaid HM, Lopez-Barcons L, Grossman A, Lia M, Keller S, Pérez-Soler R and Horwitz SB: Enhancement of the therapeutic efficacy of taxol by the mitogen-activated protein kinase kinase inhibitor CI-1040 in nude mice bearing human heterotransplants. Cancer Res 65: 2854-2860, 2005.

304. Mabuchi S, Ohmichi M, Kimura A, Hisamoto K, Hayakawa J, Nishio Y, Adachi K, Takahashi K, Arimoto-Ishida E, Nakatsuji Y, Tasaka K and Murata Y: Inhibition of phosphorylation of BAD and Raf-1 by Akt sensitizes human ovarian cancer cells to paclitaxel. J Biol Chem 277: 33490-33500, 2002.

305. Brognard J and Dennis PA: Variable apoptotic response of NSCLC cells to inhibition of the MEK/ERK pathway by small molecules or dominant negative mutants. Cell Death Differ 9: 893-904, 2002.

306. Aoki K, Ogawa T, Ito Y and Nakashima S: Cisplatin activates survival signals in UM-SCC-23 squamous cell carcinoma and these signal pathways are amplified in cisplatin-resistant squamous cell carcinoma. Oncol Rep 11: 375-379, 2004.

307.Park SA, Park HJ, Lee BI, Ahn YH, Kim SU and Choi KS: Bcl-2 blocks cisplatin-induced apoptosis by suppression of ERK-mediated p53 accumulation in B104 cells. Brain Res Mol Brain Res 93: 18-26, 2001.

308. Lunghi P, Tabilio A, Lo-Coco F, Pelicci PG and Bonati A: Arsenic trioxide (ATO) and MEK1 inhibition synergize to induce apoptosis in acute promyelocytic leukemia cells Leukemia 19: 234-244, 2005.

309. Lunghi P, Costanzo A, Salvatore L, Noguera N, Mazzera L, Tabilio A, Lo-Coco F, Levrero $M$ and Bonati A: MEK1 inhibition sensitizes primary acute myelogenous leukemia to arsenic trioxide-induced apoptosis. Blood 107: 4549-4553, 2006.

310.Dai Y, Landowski TH, Rosen ST, Dent P and Grant S: Combined treatment with the checkpoint abrogator UCN-01 and MEK1/2 inhibitors potently induces apoptosis in drugsensitive and -resistant myeloma cells through an IL-6independent mechanism. Blood 100: 3333-3343, 2002.

311. Rieber M and Rieber MS: Signalling responses linked to betulinic acid-induced apoptosis are antagonized by MEK inhibitor U0126 in adherent or 3D spheroid melanoma irrespective of p53 status. Int J Cancer 118: 1135-1143, 2006.

312. McCubrey JA, LaHair MM and Franklin RA: Reactive oxygen species-induced activation of the MAP kinase signaling pathway. Antioxid Redox Signal 8: 1745-1748, 2006.

313. Fornari FA, Randolph JK, Yalowich JC, Ritke MK and Gewirtz DA: Interference by doxorubicin with DNA unwinding in MCF-7 breast tumor cells. Mol Pharm 45: 649-656, 1994.

314. Gewirtz DA: A critical evaluation of the mechanisms of action proposed for the antitumor effects of the anthracycline antibiotics adriamycin and daunorubicin. Biochem Pharmacol 57: 727-741, 1999

315. Singal PK, Li T, Kumar D, Danelisen I and Iliskovic N: Adriamycin-induced heart failure: mechanism and modulation. Mol Cell Biochem 207: 77-86, 2000

316. Friesen C, Fulda S and Debatin KM: Induction of CD95 ligand and apoptosis by doxorubicin is modulated by the redox state in chemosensitive- and drug-resistant tumor cells. Cell Death Differ 6: 471-480, 1999

317. Narayanan PK, Goodwin EH and Lehnert BE: Alpha particles initiate biological production of superoxide anions and hydrogen peroxide in human cells. Cancer Res 57: 3963-3971, 1997.

318. Kobayashi D, Tokino $\mathrm{T}$ and Watanabe N: Contribution of caspase-3 differs by p53 status in apoptosis induced by Xirradiation. Jpn J Cancer Res 92: 475-481, 2001

319. Oleinick NL and Evans HH: The photobiology of photodynamic therapy: cellular targets and mechanisms. Radiat Res 150: S146-S156, 1998.

320. Matroule JY, Carthy CM, Granville DJ, Jolois O, Hunt DW and Piette J: Mechanism of colon cancer cell apoptosis mediated by pyropheophorbide-a methylester photosensitization. Oncogene 20: 4070-4084, 2001
321. Tong Z, Singh G and Rainbow AJ: Sustained activation of the extracellular signal-regulated kinase pathway protects cells from photofrin-mediated photodynamic therapy. Cancer Res 62: $5528-5535,2002$

322. Dent P, Yacoub A, Fisher PB, Hagan MP and Grant S: MAPK pathways in radiation responses. Oncogene 22: 5885-5896, 2003.

323. Dent P, Yacoub A, Contessa J, Caron R, Amorino G, Valerie K, Hagan MP, Grant S and Schmidt-Ullrich R: Stress and radiationinduced activation of multiple intracellular signaling pathways. Radiat Res 159: 283-300, 2003.

324. Abdelmohsen K, von Montfort C, Stuhlmann D, Gerber PA, Decking UK, Sies H and Klotz LO: Doxorubicin induces EGF receptor-dependent down-regulation of gap junctional intercellular communication in rat liver epithelial cells. Biol Chem 386: 217-223, 2005.

325. Papaiahgari S, Kleeberger SR, Cho HY, Kalvakolanu DV and Reddy SP: NADPH oxidase and ERK signaling regulates hyperoxia-induced Nrf2-ARE transcriptional response in pulmonary epithelial cells. J Biol Chem 279: 42302-42312, 2004.

326. Matsuzawa A, Nishitoh H, Tobiume K, Takeda K and Ichijo H: Physiological roles of ASK1-mediated signal transduction in oxidative stress- and endoplasmic reticulum stress-induced apoptosis: advanced findings from ASK1 knockout mice. Antioxid Redox Signal 4: 415-425, 2002.

327. Minamino T, Yujiri T, Papst PJ, Chan ED, Johnson GL and Terada N: MEKK1 suppresses oxidative stress-induced apoptosis of embryonic stem cell-derived cardiac myocytes. Proc Natl Acad Sci USA 96: 15127-15132, 1999.

328. Modur V, Zimmerman G, Prescott S and McIntyre T: Endothelial cell inflammatory responses to tumor necrosis factor alpha. Ceramide-dependent and -independent mitogenactivated protein kinase cascades. J Biol Chem 271 13094-13102, 1996.

329. Teramoto H, Coso OA, Miyata H, Igishi T, Miki T and Gutkind JS: Signaling from the small GTP-binding proteins Rac1 and Cdc42 to the c-Jun N-terminal kinase/stress-activated protein kinase pathway. A role for mixed lineage kinase 3/ protein-tyrosine kinase 1, a novel member of the mixed lineage kinase family. J Biol Chem 271: 27225-27228, 1996.

330. Ichijo H, Nishida E, Irie K, ten Dijke P, Saitoh M, Moriguchi T, Takagi M, Matsumoto K, Miyazono K and Gotoh Y: Induction of apoptosis by ASK1, a mammalian MAPKKK that activates SAPK/JNK and p38 signaling pathways. Science 275: 90-94, 1997.

331. Tobiume K, Matsuzawa A, Takahashi T, Nishitoh H, Morita K, Takeda K, Minowa O, Miyazono K, Noda T and Ichijo H: ASK1 is required for sustained activations of JNK/p38 MAP kinases and apoptosis. EMBO Rep 2: 222-228, 2001.

332. Suzaki Y, Yoshizumi M, Kagami S, Koyama AH, Taketani Y, Houchi H, Tsuchiya K, Takeda E and Tamaki T: Hydrogen peroxide stimulates c-Src-mediated big mitogen-activated protein kinase 1 (BMK1) and the MEF2C signaling pathway in PC12 cells: potential role in cell survival following oxidative insults. J Biol Chem 277: 9614-9621, 2002.

333. Kamakura S, Moriguchi T and Nishida E: Activation of the protein kinase ERK5/BMK1 by receptor tyrosine kinases. Identification and characterization of a signaling pathway to the nucleus. J Biol Chem 274: 26563-26571, 1999.

334. Cavanaugh JE, Ham J, Hetman M, Poser S, Yan C and Xia Z: Differential regulation of mitogen-activated protein kinases ERK1/2 and ERK5 by neurotrophins, neuronal activity, and cAMP in neurons. J Neurosci 21: 434-443, 2001.

335. Touyz RM, Yao G, Viel E, Amiri F and Schiffrin EL: Angiotensin II and endothelin-1 regulate MAP kinases through different redox-dependent mechanisms in human vascular smooth muscle cells. J Hypertens 22: 1141-1149, 2004. 